\title{
Акцентная система пракельтского языка на фоне акцентных систем других северо-западных индоевропейских языков
}

\begin{abstract}
В работе автор возвращается к своим результатам 1961 года, касающимся сокращений индоевропейских долгот в безударном слоге в кельто-италийских языках. Найдено значительное количество нового подтверждающего материала к первоначальной гипотезе; при этом результаты модифицированы за счет демонстрации еще одного типа рефлексов сокращения долгих сонантов в кельтских языках. Также показана конгруэнтность описаний найденных закономерностей в ларингалистской и традиционной интерпретациях.
\end{abstract}

Ключевые слова: акцентологическая реконструкция, кельтские языки, сокращения долгот, акцентные парадигмы, метатония.

В связи с установлением рефлексов двух акцентных парадигм германских глаголов с корнями на нешумные (см. [Дыбо 2015а]) мы возвращаемся к реконструированным мной в 1961 г. двум кельто-италийским акцентным парадигмам отглагольных имен с основами на -tu- и -to- (в латинском они выступают в качестве супинов и причастий), а также подобных отглагольных имен с суффиксом -nо-. Ввиду некоторого улучшения состояния дел в кельтской этимологии и определенного завершения реконструкции балтославянской акцентной системы мы представим здесь наши сближения этих форм в несколько обновленном виде:

\section{А. Кельто-итадийские окситона.}

\section{-to-основы:}

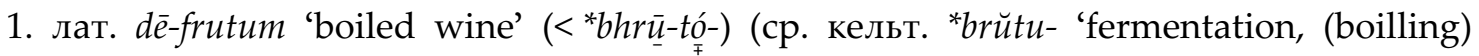
heat' [Noun]: см. ниже -tи-основы, п. 2) др.-исл. brugga 'brauen'; слав. *brujäti, *brujíti,

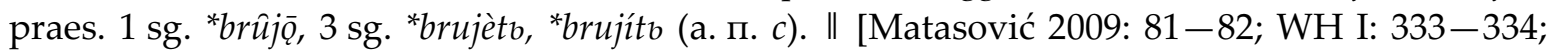
Orel 2003: 56-57; IEW: 143-145].

К структуре корня: и.-е. корень *bhrēu-/*bhrū- (в ларингалистической интерпретации: * $b h r e h_{1} u-{ }^{*} b h r_{0} u$-):

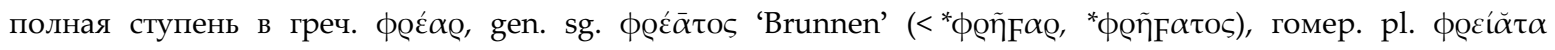

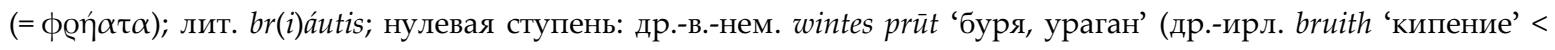
*bhrŭti-<*bhrütí-, см. [Дыбо 1961: 11]) и ср.-ирл. bruth 'Glut', валл. brwd 'das Brauen; so viel Bier, wie auf einmal

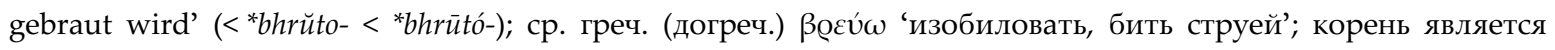
расширением и.-е. базы (второй основы) от корня *bhera- 'aufwallen, sich heftig bewegen': др.-инд. bhuráti 'bewegt sich rasch, zuckt, zappelt' (< *hhr̄-e-ti), bhûrnii-h 'heftig, zornig, wild, eifrig' (< *bhr̄ni-); полная ступень второй основы в герм. *brēja- (крым. гот. breen 'schmoren'; ср.-в.-нем. bræjen 'riechen, duften', ср.-нидерл. bræyen 'braten’) и в герм. *brēđa- (др.-исл. brádr adj. ‘горячий, вспыльчивый, опрометчивый’; др.-англ. bró́; тж. лат. frĕtum n. 'прибой, прилив; бушевание, волнение; жар, пыл’ < *bhrěto- < *bhrētó-, см. [Дыбо 1961: 14]). ॥ [Orel 2003: 56 (герм. *brewwan); ЭССЯ 3: 45-46; IEW: 144-145 (ฟ*bhrӗu-/*bhrŭ- и (??) ฟ*bhréu-/*bhruu-), 132-133 


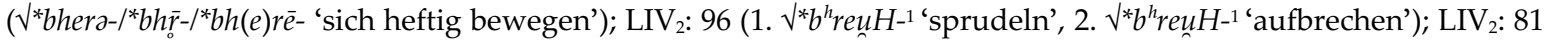
$\left(\sqrt{ }{ }^{*} b^{h} e r h_{2^{-1}}\right.$ 'sich schnell bewegen')].

2. кельт. *bŭto- [part. praet. pass.], кельт. *bŭtā- 'place, dwelling, hut' [ā f.]; лат. *fŭto(<*bhū-tó-, в fütāre), ср. лат. fŭtu- (<*bhū-tú- в fŭturus) лтш. bût, супин bûtu, part. praet. bûts, gen. sg. nио bûtu dienu [Endz.Gr. 798]; слав. *bȳti; l-part. bŷlt, f. *bylä, n. *bŷlo. II [Matasović 2009: 85, 84-85; Дыбо 1961: 12, 30, 31; Дыбо 2000: 500, 516, 517; WH I: 557-559; IEW: 146 150].

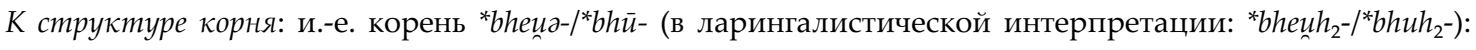

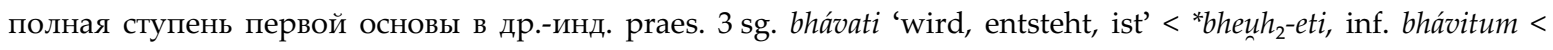
“bheu h. $h_{2}$-tum; авест. bhavaiti 'wird, ist'; др.-англ. bēo 'ich bin' (?) < *bheuō < *bheuh ${ }_{2}-o h_{2}$; полная ступень второй основы: др.-лат. praes. subiūnct. fuam 'sei'; нулевая ступень: др.-инд. part. praet. pass. bhūtáh̆ 'geworden, verwan-

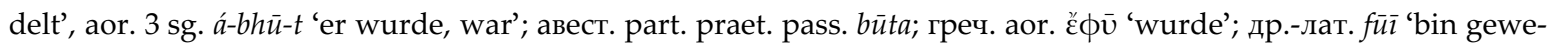
sen’; др.-лит. aor. bü, др.-лтш. buvи 'ich war'; ст.-слав. вы. ॥ [KEWA II: 485-487; EWA II: 255-257; Frisk 19601972 II: 1052-1054; WH I: 557-559; IEW: 146-150; LIV 2 : 98-101 ( ${ }^{*} b^{h}{ }_{n}^{h} h_{2^{-1}}{ }^{-1}$ wachsen, entstehen, werden')].

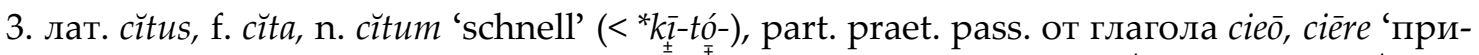

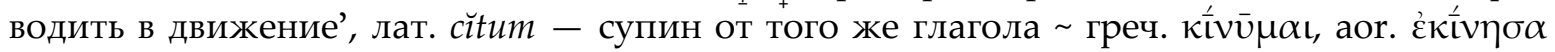
'setze in Bewegung, treibe'; кі́ 'gehe weg, fahre'. ॥| [Дыбо 1961: 30; Fraenkel 1962-1965: 251; WH I: 213-214; Frisk 1960-1972 I: 855, 862-863; IEW: 538-539 (ل`*keì-)].

К структуре корня: и.-е. корень *kēi-/*ki- 'in Bewegung setzen, in Bewegung sein' (в ларингалистической интерпретации: *keh $\left.h_{1} i_{-}{ }^{*} k h_{1} i-\right)$ : полная ступень, по-видимому, в лит. kiele (1) 'Bachstelze', 'трясогузка'; лтш. ciẽlava 'трясогузка' от и.-е. *kēilos (> прабалт. *kielas) ‘подвижный’ > (?) лтш. диал. ciẽls 'gross’; слав. *čílt, f. *číla, n. *č́lo ‘бодрый, живой, крепкий’ [схрв. чйл, -a, -о 'крепкий, сильный', словен. č́l, číla 'отдохнувший, бодрый’, ст.-чеш. čilý 'свежий, живой, бодрый’, в.-луж. čily 'невредимый; бодрый, крепкий’]; нулевая ступень в греч.

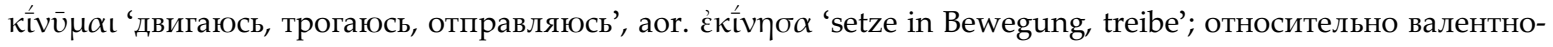
сти корневой морфемы ср. еще слав. *с̌́t 'целый, здоровый, крепкий', но лит. kíetas (3) 'твердый, жесткий, крепкий', лтш. ciêts 'твёрдый, жесткий' (однако с колебанием а. п. в древнелитовском: f. gen. sg. kietós DP $476_{37}$ и kiétos DP 312 20 , при отражении рецессивности в словообразовании: gen. sg. m. kietúmo DP 293 ${ }_{28}, 477_{43}$ ). ॥ [Дыбо 1961: 30; Fraenkel 1962-1965: 251, 252; Karulis 2001: 170-171, 173; WH I: 213-214; Frisk 1960-1972 I: 855, 862-863; IEW: 538-539 ( ${ }^{*} k \bar{e} i-$ 'in Bewegung setzen, in Bewegung sein'); $\operatorname{LIV}_{2}$ : $346\left({ }^{*}{ }^{*} \hat{k} e i h_{2^{-}}\right.$'sich in Bewegung setzen')].

4. лат. frĕtum, -ī n. (<*frē-tó- < * bhrēe-tó-) 'Brandung, Wallung des Meeres' (ср. лат. frĕtus, -йs m. (<*frē-tú-) 'Brandung, Wallung des Meeres' др.-инд. bhú rṇi-ḥ 'heftig, eifrig', bhuráti 'bewegt sich, zuckt, zappelt'; герм. ‘brejan-: гот. (крым.) breen 'to roast'; ср.-нидерл. bræyеn 'braten', ср.-в.-нем. bræjen 'riechen, duften', с закономерным сохранением долготы в отглагольных именах с дентальными суффиксами: герм. *brēđaz adj. (<*brēpá-) [др.-исл. bráðr adj. 'hasty, sudden']; и с подтверждением первичной окситонезы производящего в отыменном глаголе: герм. *brēđjan-. ॥ [WH I: 546-547; Feist 1939: 104-105; Orel 2003: 57; IEW: $132-133,137]$.

К структуре корня: и.-е. корень “bhrē-/*bhrz- 'sieden, wallen; sich schnell bewegen' (в ларингалистической

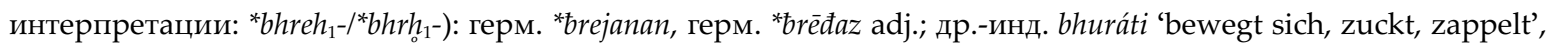
bhúrnih 'heftig, zornig, wild, eifrig'; -о-ступень в германском: др.-англ. brōd f. 'Brut, Zucht'; ср.-в.-нем. bruot f. 'Hitze, Brut'; рецессивная валентность корневой морфемы устанавливается по конечному ударению германских отглагольных имен с дентальными суффиксами. ॥[ [Дыбо 1961: 28; WH I: 546-547; de Vries 1977: 52; Orel

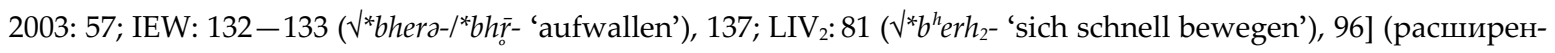
ный $\sqrt{ }^{*} b^{h}$ reuH- 'sprudeln', но отмечается [Rasmussen 1989: 97] $\left.{ }^{*}{ }^{*}{ }^{h} r e h_{1} u-\right)$. 
5. др.-лат. *gnŏtus 'известный’ (< *ĝnō-tó-): лат. nŏta f. 'знак, отметка', nŏtāre 'обозначать, отмечать', cognitus 'известный, знакомый', agnitus 'признанный', предполагают др.-лат. * gnŏtus 'известный'. ॥ [Дыбо 1961: 13; WH II: 177-178; IEW: 376-378].

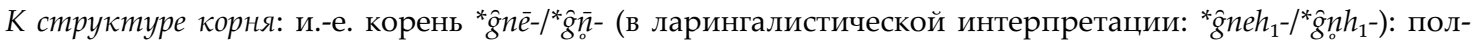
ная ступень в тох. А kña- 'знать', 'kennen'; o-ступень: др.-перс. xšnāsa- в xšnāsāhiy 'du sollst merken', греч. эпи-

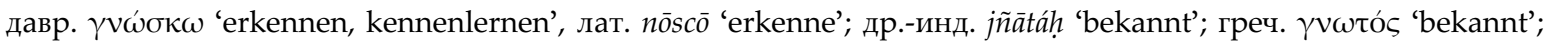

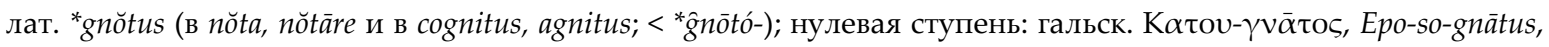
др.-ирл. gnäth 'gewohnt, bekannt' < *ôñnto-; герм. *kúnp-az (гот. kunp-s 'bekannt'; др.-исл. kunnr, kuðr 'bekannt, kundig'; др.-англ. си́ð 'kund, bekannt, offenbar, sicher; ausgezeichnet; freundlich, verwandt', др.-фриз. küth 'kund, bekannt', др.-сакс. kūth 'bekannt', др.-в.-нем. kund 'bekannt, kund; verwandt'), “un-kúnp-az (гот. un-kunp-s 'unbekannt'; др.-исл. и́-kúdr 'unbekannt'; др.-англ. иn-си́ð 'unknown, uncertain, strange, terrible', ср.-нидерл. оncont 'onbekend aan, onbekend met', др.-в.-нем. un-kund 'unbekannt'); лит. pažintas 'bekannt', лтш. pazĩts 'знакомый’ < *ăgn to-; нулевая ступень с инфиксным рассечением (тест 9 класса): авест. zanā-ț, zanšn, афг. pe-žanı 'un-

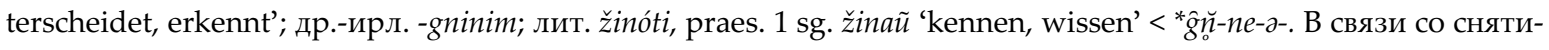
ем долготы в латинском следует предполагать нисходящий тон в корневой морфеме. II [Orel 2003: 224; IEW:

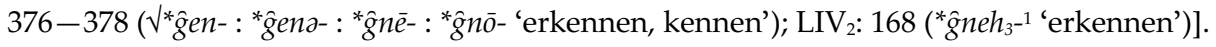

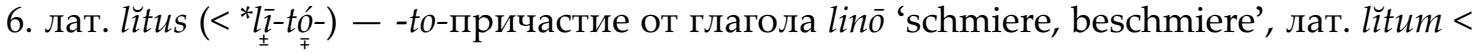
*lītú-, супин от того же глагола; кельт. *li-na- 'stick' [Vb] др.-инд. lināti (Dhātup.), а также

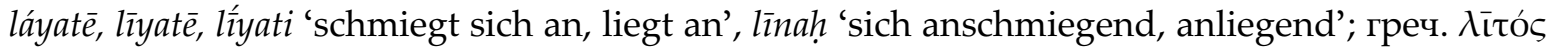
'гладкий'. || [WH I: 807-808; Matasović 2009: 239; KEWA III: 102-103; IEW: 662-663].

К структуре корня: и.-е. корень *əleiz-/*ali- 'sich anschmiegen, beschmieren, bestreichen, salben' (в ларингалистической интерпретации: * $h_{2} l e i H-/ * h_{2} l i H$ - 'sich anschmiegen, beschmieren, bestreichen, salben'): др.-инд. linát $i$ (gramm.), láyatē, lìyatē, líyati 'schmiegt sich an, liegt an, bleibt stecken, verschwindet', linnạ 'sich anschmiegend, an-

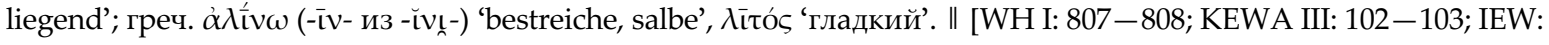

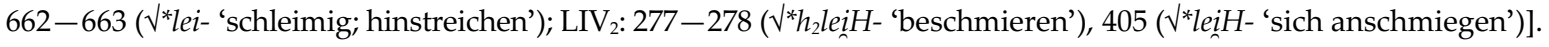

7. лат. pŭtus adj. 'rein' (<*pūtó-), pūrus, -a, -um 'rein; lauter'; кельт. *fūro- 'fresh' [Adj.]

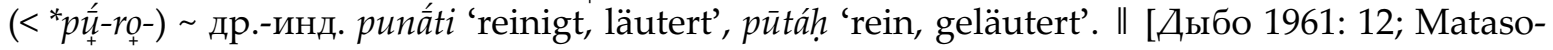
vić 2009: 143; WH II: 393-394, 390-391; IEW: 827; LIV 2: 480].

К структуре корня: и.-е. корень “реиа-/* рй- 'reinigen, läutern, sieben' (в ларингалистической интерпретации: " 'rein', púti- f. 'Reinigung', pavitár- 'Reiniger, Läuterer'; лат. pūrus 'rein'; ср.-ирл. ūr 'neu, frisch, edel', валл. ir

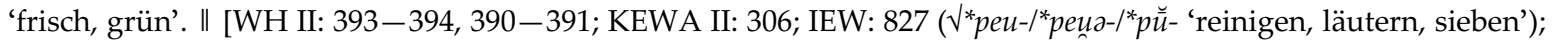
$\mathrm{LIV}_{2}: 480\left(\sqrt{ }{ }^{*}\right.$ peuH- 'reinigen, läutern')].

8. лат. rŭtum n. 'das Aufschlagen' (<*rūtó-); лат. rūo, rū̄, ruitūrus, -ere 'stürze, eile' др.-инд. rāvișam 'ich mag zerschlagen’; лит. ráuti, praes. $1 \mathrm{sg}$. ráuju, диал. ráunu, praet. $1 \mathrm{sg}$. róviau 'raufen, mit der Wurzel ausreißen, rupfen, abreißen, aushacken, hinwegraffen'; лтш. raût, praes. 1 sg. raйји и диал. raи̂nu, praet. 1 sg. rāvu 'reißen, raufen, ziehen, raffen, stehlen'; слав. *rbváti, praes. $1 \mathrm{sg}$. *rövQ, 3 sg. *rbvètb; aor. 1 sg. *rbväxb, 2-3 sg. *röva, l-part. *rb̈valı, f. rbvalä, n. * rb̈valo и * rũti (< ${ }^{*}$ rutî); praes. $1 \mathrm{sg} .{ }^{*}$ rûjo, $3 \mathrm{sg} .{ }^{*}$ rujètb; l-part. *rûlb, f. * rulä, n. *rûlo. || [WH II: 453, 453-454; Fraenkel 1962-1965: 708-709; Дыбо 2000: 286, 498, 511; KEWA III: 63; IEW: 868].

K структуре корня: и.-е. корень "rāu-/ ${ }^{*} r \bar{u}-$ 'aufreißen' (в ларингалистической интерпретации: 'reh 2 и-

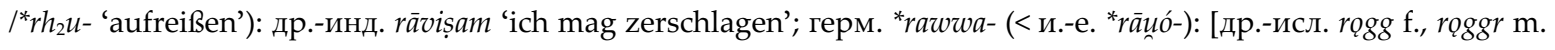
'langes Haar, lange Wolle', швед. rugg 'zottiges Haar']; лит. ráuti; лтш. raût; слав. " rbváti и *rũti (< *rutí). ॥| [IEW:

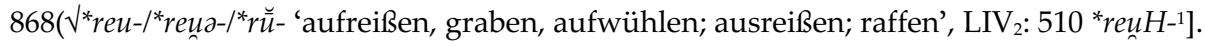


9. кельт. *tantā- (<*tn̄ttá-) 'cord, cable' [Noun] лит. tìnti, praes. $1 \mathrm{sg}$. tìnstu и tístu; лтш. tît, praes. $1 \mathrm{sg}$. tinu и tiņu, praet. $1 \mathrm{sg}$. tinu 'winden, wickeln, flechten'; др.-инд. tanốti, tanuté 'dehnt, spannt, erstreckt sich, dauert', pass. tāyáte, Dhātup. tấyate 'breitet sich aus, geht vorwärts', uttānáh 'ausgestreckt' (<*-tñ-nó-), tani-man- n. 'Dünne'. \|| [Matasović 2009: 369-370; Fraenkel 1962-1965: 1099; KEWA I: 475, 496; IEW: 1065-1066].

К структуре корня: и.-е. корень *tenд-/*tп̄- ‘dehnen, ziehen, spannen' (в ларингалистической интерпретации: *tenH-/*tnН-): др.-инд. tanốti, tanuté 'dehnt, spannt, erstreckt sich, dauert', pass. tāyáte, Dhātup. tấyate 'breitet sich aus, geht vorwärts', uttānáh 'ausgestreckt' (<*-tñ-nó-), tani-man-n. 'Dünne'; лит. tìnti, praes. 1 sg. tìnstu и tístu,

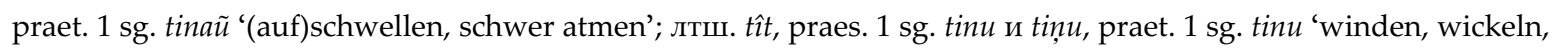
flechten'. II [Matasović 2009: 369-370; Fraenkel 1962-1965: 1099; KEWA I: 475, 496; IEW: 1065-1066].

10. кельт. *-balto- (<*-gū -tó-) (др.-ирл. at-ru-balt 'mortuus est' от др.-ирл. at-baill 'stirbt') лит. gélti; лтш. dzelt 'stechen, brennen, beissen'; герм. *kwelan- 'to suffer, die’. ॥ [Дыбо 1961: 22; Льюис-Педерсен 1954: 400; Matasović 2009: 53; Fraenkel 1962-1965: 145-146; Kroonen 2013: 316; IEW: 470-471].

К структуре корня: и.-е. корень ${ }^{*} g^{u} \bar{e} l-/^{*} g^{u} \bar{l}-$ 'stechen, schmerzen, sterben' (в ларингалистической интер-

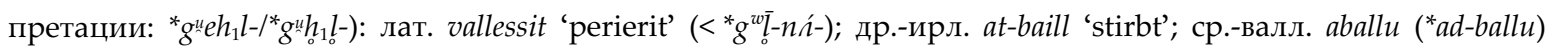
'umkommen', ballu 'sterben'); герм. *kwelanan: [др.-англ. cwelan 'sterben', др.-в.-нем. quelan 'schmerzen, leiden']; лит. gilti, gélti, praes. 3 sg. gẽlia 'жалить, кусать; болеть, ныть, ломить'; лтш. dzelt 'stechen, brennen, beissen'; полная ступень в гетеросиллабической позиции: др.-в.-нем. quâla 'му́ка'; лит. gèlà (4<*3) 'heftiger Schmerz';

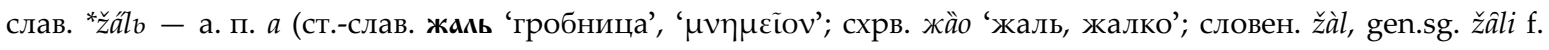
'das Leid, der Schmerz', с новым циркумфлексом в род. падеже; ср. также ударение в отыменном глаголе: др.-русск. жа́лнти(сл, -си) 'жалеть', ‘жаловаться’ [Зализняк 2014: 298]). ॥| [Matasović 2009: 53; Дыбо 1961: 22; Plet. II: 952; Дыбо 2007: 22; WH II: 729-730; Mühl.-Endz. I: 541; Fraenkel 1962-1965: 145-146; Orel 2003: 227; IEW: 470-471 ( ${ }^{*} g^{u} e l-$ 'stechen', '(stechender) Schmerz, Qual, Tod'); $\operatorname{LIV}_{2}: 207\left(\sqrt{ }^{*} \mathrm{~g}^{u} \mathrm{elH}\right.$ - 'quälen, stechen')].

11. кельт. *falto- 'joint' [Noun] (< ${ }^{*} p \bar{\imath}-$-tó- $<{ }^{*} p l H$-tó-) др.-инд. puṭa- m., n. 'Falte, Tüte, Tasche' (< *pulta-); герм. *falpan- 'to fold, ply'. II [Matasović 2009: 121; Feist 1939: 141-142; Orel 2003: 91; Kroonen 2013: 126; WH II: 276-277; Frisk 1960-1972 II: 536, 494-495; IEW: 802803, 803-804].

К структуре корня: и.-е. корень “pelə-/*plē-/* $p \bar{l}-$ 'falten; verdecken, verhüllen' (в ларингалистической ин-

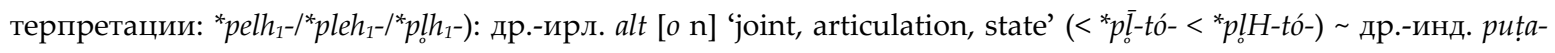

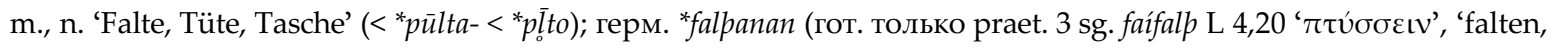
zusammenrollen'; др.-исл. falda, praet. felt, part. praet. faldenn 'den Kopf bedecken. ॥ [Matasović 2009: 121; Seebold 1970: 183-185; Feist 1939: 141-142; Orel 2003: 91; WH II: 276-277; Frisk 1960-1972 II: 536, 494-495; IEW: 802-803, 803-804 ( ( * pel- 'falten', *pela-/*plē- 'verdecken, verhüllen'); $\operatorname{LIV}_{2}: 471$ (? ฟ*pelk- 'einhüllen, verbergen')].

12. (?) кельт. * skanto- 'Schuppen' $\left(<{ }^{*}(s) k \bar{n} t t_{\mp}-<{ }^{*}(s) k h_{0} 1 n t o ́-;\right.$ [Matasović 2009]: < *skn-to-): брет. skant 'Schuppen'; др.-брет. *scanto- в anscantocion pl. 'in-squamōsos', 'sans écale' (Loth),

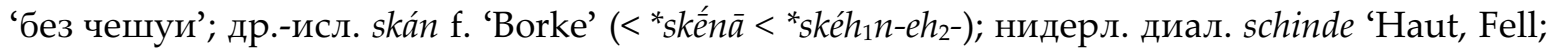
Bast, Rinde’ (<*skeh $n$ đà-). II [Loth 1883: 41, 405f; Matasović 2009: 201 (<*skn-to-); de Vries 1977: 493, 482; IEW: 929].

К структуре корня: и.-е. корень *skēn-/*skñ- 'schinnen, sich häuten', (?) ‘schinden' (в ларингалистической интерпретации: *skehn-/*skhon-): брет. skant 'Schuppen', 'dandruff', 'перхоть'; др.-брет. *scanto- в anscantocion pl. 'in-squamōsos', 'sans écale’ (Loth), ‘без чешуи'; валл. ysgyhru 'Schnitzen' (< *sken-tr-); др.-исл. skinn n. 'Наut,

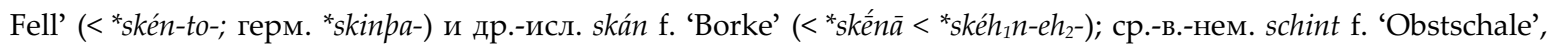
нов.-в.-нем. Schind-mähre, -аas; нидерл. диал. schinde 'Haut, Fell; Bast, Rinde'. II [Loth 1883: 41, 405f; Matasović 2009: 201 (<*skn-to-); de Vries 1977: 493, 482; IEW: 929 ( $ل^{*}(s) k e n-(d-)$ 'abspalten; abgespaltene Haut, Schuppe, Rinde')]. 


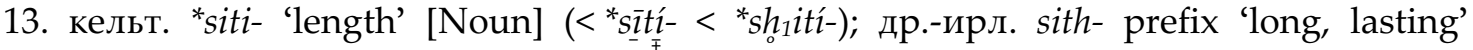
(< кельт. " sita- < *sītó- < *saitó- < *sho 1 itó-) герм. *sīđáz < *sīpás adj. 'herabhängend'. II [Matasović 2009: 338, 337; Feist 1939: 415-416; Orel 2003: 329; IEW: 890-891; Isaac 2007: 28 $\left(<{ }^{*}\right.$ seh $\left.\left._{1}-t i^{-}\right)\right]$.

К структуре корня: и.-е. корень ${ }^{*}$ sēi-/*sai-/*sī- 'entsenden, werfen, fallen lassen (spät, langsam, langdauernd)' (в ларингалистической интерпретации: * $\left.{ }^{*} h_{1} i-{ }^{*}{ }^{*} h_{0}{ }_{1} i-{ }^{*}{ }^{*} h_{1} i\right):-e-$-ступень: др.-инд. вед. sáyaka- m., n. 'Wurfgeschoß', 'метательное орудие; метательное копье; дротик'; -о-ступень: др.-инд. вед. ava-sāyáyati 'läßt ausspannen'; нулевая ступень в гетеросиллабической позиции: др.-инд. вед. (áva,vî) syáti 'macht los, spannt aus', греч. ín $\mu \mathrm{t}$ 'werfe, sende'; хетт. siēzzi 'schießt'; нулевая ступень в таутосиллабической позиции: герм. *sīđa-z adj. 'herabhängend'; лат. situs 'gelegen', ср.-ирл. sith- 'lang' (< * sitto- < *sittó-), перед первично доминантным суффиксом: лат. saeculum 'Geschlecht, Menschenalter, Jahrhundert'; валл. hoedl 'Lebensdauer', др.-брет. hoetl, cp.-

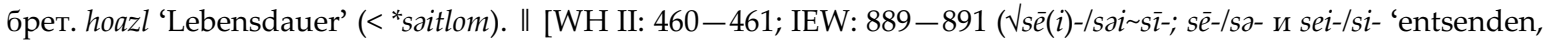
werfen, fallen lassen, säen'); $\operatorname{LIV}_{2}: 518\left({ }^{*}{ }^{*} \operatorname{seh}_{1}(i)^{-1}{ }^{-1}\right.$ loslassen')].

14. кельт. *muto- 'penis' [Noun] (< лат. толео̄ 'setze in Bewegung, bewege hin und her, rühre, schüttle; bewege fort, entferne' др.-инд. mívoati 'schiebt, drängt, bewegt', káma-mūta- 'von Liebe bewegt, von Begierde getrieben', лит. máuti, лтш. maи̂t 'an-, aufziehen; zäumen; hindurchzudringen versuchen'. ॥ [Matasović 2009: 282; WH II: 116, cp. 137-138, 138 (2.); IEW: 743; LIV 2: 445-446].

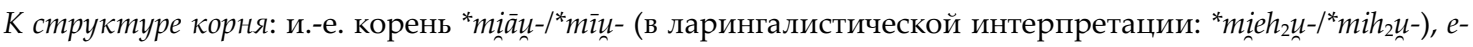
ступень: лит. йžmova (1) 'насадка', иžmоvìmas (2) 'насадка, надевание’; др.-инд. mív ati 'schiebt, drängt, bewegt', kấma-mūta- 'von Liebe bewegt, von Begierde getrieben', mūrá- 'drängend, eilend'; авест. ava-mìvoàmahi 'wir beseiti-

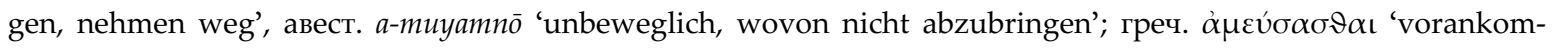

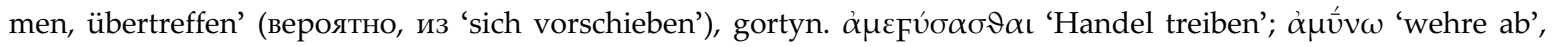
Med. 'verteidige mich ('schiebe weg)', лат. movēo, mōvī, mōtum ("movitum), -ère 'setze in Bewegung, bewege hin und her, rühre, schüttle; bewege fort, entferne'; лит. máuti, praes. 1 sg. máuju и та́ипu, praet. 1 sg. móviau 'надевать, напяливать; быстро (энергично) двигать(ся)', лтш. mâ̂t, praes. 1 sg. mauju и maunu, praet. māvu 'an-, aufziehen; zäumen; hindurchzudringen versuchen'. Если к этому корню относится и слав. *mÿti, praes. 1 sg. *mýio, 3 sg. *mýietb, то мы должны принять двойственность выбора акцентуационной валентности, т. е. нисходящий тон корневой морфемы. Это поддерживает и др.-инд. ved. mútram n. 'Harn, urine', при высоком тоне ударение должно было стоять на втором слоге. ॥ [Matasović 2009: 282; WH II: 116, cp. 137-138, 138 (2.); IEW:

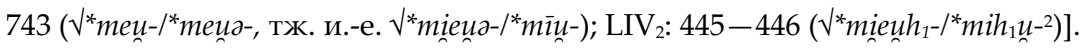

15. кельт. *-kluto- (< *klu-to- < *k̂k ū-tó-) 'heard' герм. *xlūđaz < *xlūpáz; лтш. slūt 'слыть'; слав. ${ }^{*}$ slÿti, praes. 1 sg. * slöve, 3 sg. *slovètb; l-part. slŷlb, f. *slylä, n. *slŷlo. II [McCone 1991: 13; Matasović 2009: 208; Дыбо 2000: 286].

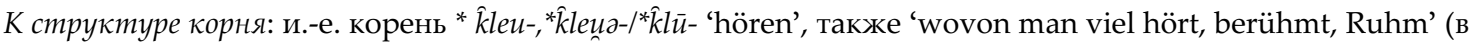
ларингалистической интерпретации: $\left.{ }^{*} k l e u-,{ }^{*} k l e u H-/{ }^{*} k l u H-\right)$ : др.-инд. śrnóti (*k̂̀l-neu-) 'hört', śrudhí 'höre'

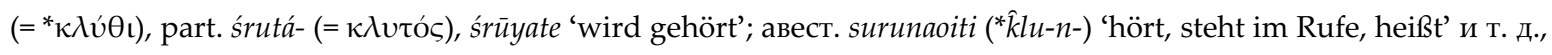

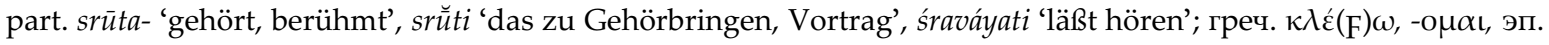

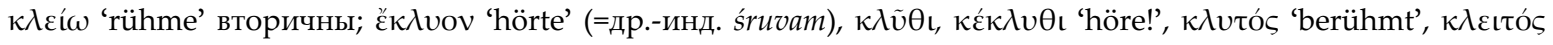

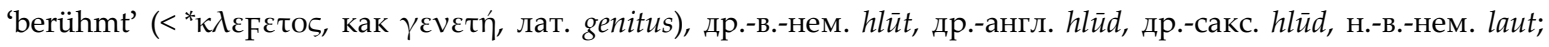
лат. inclutus 'berühmt'; др.-ирл. cloth n. 'Ruhm', валл. clod 'laus'; герм. *hluða- в др.-в.-нем. Hluderīch, Hlothari, др.-англ. Hlop-wīg, -here и т. д.; с $\bar{u}$ (как в др.-в.-нем. hlūt, см. выше): др.-в.-нем. lūstrēn, н.-в.-нем. (шваб.-бавар.) laustern 'zuhören, horchen', н.-в.-нем. lauschen (“hlüs-skōn); ц.-слав. slyšati 'hören', sluchъ 'Gehör', slušati (серб. slüšati, тж. см. slyšati) 'hören’; лит. klausaũ, -ýti 'hören', лтш. klàusît 'hören, gehorchen', др.-прусc. klausîton 'erhören', лит. paklusnùs 'gehorsam' (против лит. kláusiu 'frage' = '*will hören' из *kleuə-s-ī̄). Кельтская и славянские

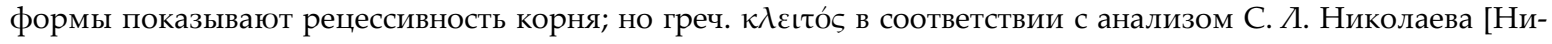




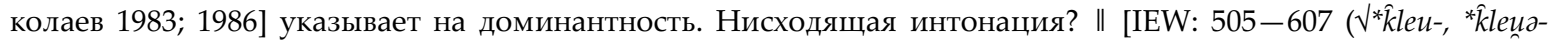

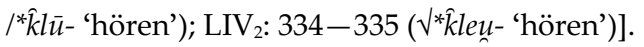

\section{-tu-основы:}

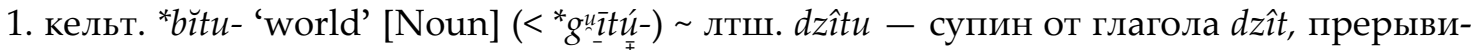
стая интонация указывает на подвижную прабалтийскую а. п., которой в кельтском может соответствовать окситонеза соответствующих форм; слав. žíti, praes. $1 \mathrm{sg}$. *žîvo, $3 \mathrm{sg}$.

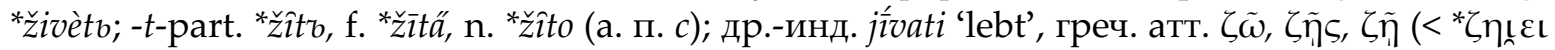
< и.-е. * ${ }^{u}$ üie-). ॥| [Matasović 2009: 67; Irslinger 2002: 84-85; Дыбо 1961: 11; Дыбо 2000: 287288, 496, 509, 515; KEWA I: 439; Frisk 1960-1972 I: 237-239; IEW: 467-469; LIV 2: 215-216].

K структуре корня: и.-е. корень ${ }^{*} g^{u} i \bar{e}-{ }^{*} g^{u} \bar{\tau}-/^{*} g^{u} i \bar{o}-$ 'leben' (в ларингалистической интерпретации:

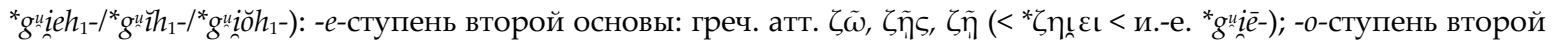

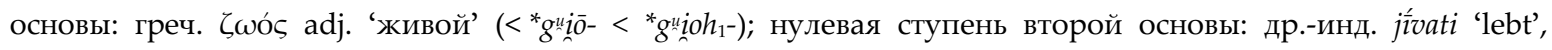

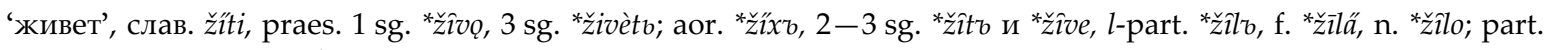

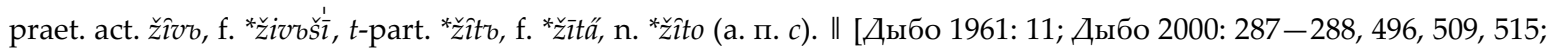

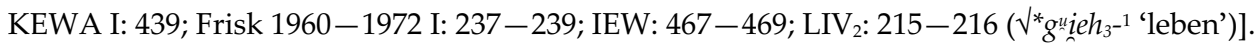

2. кельт. *brŭtu- 'fermentation, (boilling) heat' [Noun] (< *bhrūtú-) лат. dé-frutum 'boiled wine' др.-исл. brugga 'brauen'; др.-в.-нем. briuwan 'brew'; слав. *brujäti, *brujúti, praes. 1 sg. *brûjō, 3 sg. *brujètb, *brujítb (а. п. c). ॥| [Matasović 2009: 81-82; WH I: 333-334; Orel 2003: 56-57; IEW: 143-145].

К структуре корня: см. под А. -to-основы, 1, лат. dé-frutum.

3. лат. fŭtu- (<*bhūtú- в fŭturus) лтш. bît, супин bûtu, part. praet. bîts, gen. sg. nuо bûtu dienu [Endz.Gr. 798]; слав. *bÿti, aor. 1 sg. *bÿxъ, 2-3 sg. *bŷstb; l-part. bŷlı, f. *bylä, n. *bŷlo а. п. с. ॥ [Matasović 2009: 85, 84-85; Дыбо 1961: 12, 30, 31; Дыбо 2000: 500, 516, 517; WH I: 557-559; IEW: 146-150].

К структуре корня: см. под А. -to-основы, 2, кельт. buto-.

4. лат. cĭtum (< * $\left.k_{ \pm}+u_{\mp}-\right)$ - супин от глагола cieō, ciēre 'приводить в движение' греч.

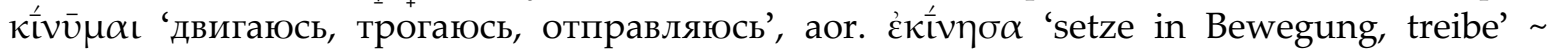
др.-чеш. čilý 'lebhaft' (краткость корневого гласного указывает на а. п. с в славянском. ॥ [Дыбо 1961: 30; WH I: 213-214; Frisk 1960-1972 I: 855, 862-863; IEW: 538-539].

К структуре корня: см. под А. -to-основы, 3, лат. č̆tus.

5. лат. frĕtus, -ūs m. 'Brandung, Wallung des Meeres', 'прибой, прилив, волнение; жар, пыл' (< ‘frē-tú-) др.-инд. bhúrnị-ḥ 'heftig, eifrig', bhuráti 'bewegt sich, zuckt, zappelt'; герм. *brejan-: гот. (крым.) breen 'тушить, жарить'; ср.-нидерл. bræyen 'braten', ср.-в.-нем. bræjen 'riechen, duften'. II [WH I: 546-547; Feist 1939: 104-105; Orel 2003: 57; IEW: 132-133, 137].

К структуре корня: см. под А. -tо-основы, 4, лат. frĕtum.

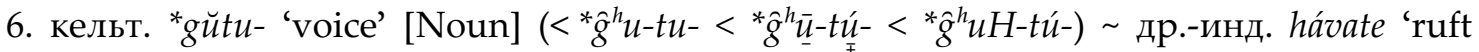
(an)', pass. hūyáte, part. praet. pass. hūtá- 'angerufen'; слав. praes. 1 sg. *zövQ, 3 sg. *zovètb; inf. sup. *zbväti, *zb̋vatı - а. п. c. II [Irslinger 2002: 26; Matasović 2009: 169-170; Дыбо 1961: 30, 31; Дыбо 2000: 273, 485, 505-506, 514-515; Фасмер I: 85; KEWA III: 585-587; Fraenkel 1962-1965: 1293; Feist 1939: 207-208 и 227-226; IEW: 413-414].

К структуре корня: и.-е. корень * $g h e u \partial-/{ }^{*} h \bar{u}$ - 'rufen' (в ларингалистической интерпретации: *gheuH^*ğhuH- 'rufen'): др.-инд. hávate 'ruft, ruft an', 'calls, invokes', pass. hūyáte, part. praet. pass. hūtá- 'angerufen, her- 


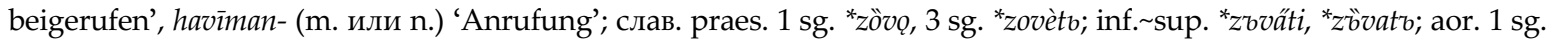

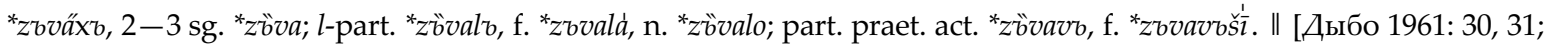
Дыбо 2000: 273, 485, 505-506, 514-515; Фасмер I: 85; KEWA III: 585-587; Fraenkel 1962-1965: 1293; Feist 1939: 207-208 и 227-226; IEW: 413-414; $\operatorname{LIV}_{2}$ : 180-181 ( ${ }^{*} \hat{g}^{h} u e H-$ 'rufen')].

7. лат. lĭtum (< $\left.{ }^{*} \underline{\imath} \underline{\imath}+u_{\mp}-\right)$ - супин от глагола linō 'schmiere, beschmiere'; лат. lĭtus adj. (<*lītó-) 'намазанный'; кельт. *li-na- 'stick' [Vb] др.-инд. lināti (Dhātup.), а также láyatē,

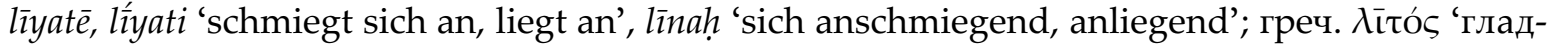
кий’. I [WH I: 807-808; Matasović 2009: 239; KEWA III: 102-103; IEW: 662-663].

К структуре корня: см. под А. -to-основы, 6, лат. lĭtus.

8. кельт. ruth 'Umstürzen, Vernichten', лат. rŭtus, -ūs 'das Aufschlagen' (<*rūtú- < ${ }^{*} r u H-$ tú-); лат. rū̄, rū̄, ruitūrus, -ere 'stürze, eile’ др.-инд. rāvișam 'ich mag zerschlagen'; лит. ráuti, praes. $1 \mathrm{sg}$. ráuјu, диал. ráunu, praet. $1 \mathrm{sg}$. róviau 'raufen, mit der Wurzel ausreißen, rupfen, abreißen, aushacken, hinwegraffen'; лтш. râ̂t, praes. 1 sg. râิju и диал. raи̂nu, praet. $1 \mathrm{sg}$. rāvu 'reißen, raufen, ziehen, raffen, stehlen'; слав. *rbvâti, praes. $1 \mathrm{sg}$. *rüvq, $3 \mathrm{sg}$. *rbvètb; aor.

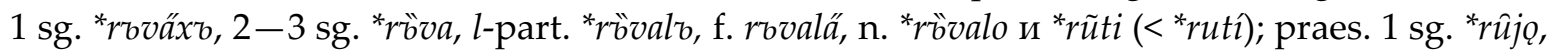
3 sg. *rujètb; l-part. *rûlt, f. *rulä, n. *rûlo. II [Irslinger 2002: 26; WH II: 453, 453-454; Fraenkel 1962-1965: 708 -709; Дыбо 2000: 286, 498, 511; KEWA III: 63; IEW: 868].

К структуре корня: см. под А. -tо-основы, 8, лат. rйtum.

9. лат. vitus 'Radfelge' (< *vītú- или *vītú-) др.-инд. vītás 'запутанный, витой' лит. výtas, лтш. vîts 'gewunden' слав. part. *vîtъ, f. *vitä, n. *vîto. ॥[ [Дыбо 2000: 283, 330, 489, 495, 508, 515, 523 (Дыбо 1981: 221); Зализняк 2011, II: 135].

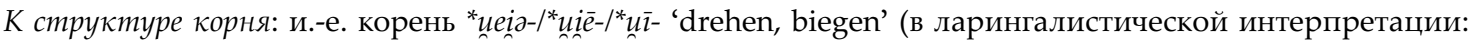

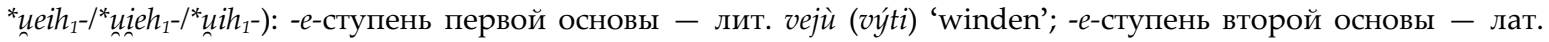
uіе̄, uiēre 'binden, flechten'; просодические отношения - лтш. inf. vît 'winden, flechten'; слав. praes. $1 \mathrm{sg}$.

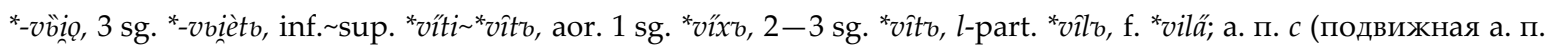
и, следовательно, рецессивная валентность корневой морфемы). ॥ [Fraenkel 1962-1965: 1267; Дыбо 2000: 283, 330, 489, 495, 508, 515, 523 (Дыбо 1981: 221); Зализняк 2011, II: 135; IEW: 1120-1121 (ل*uei-/*ueiz-/*ūi- 'drehen, bie-

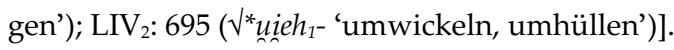

\section{-по-оснОВЫ:}

1. кельт. *darno- 'piece, part' (<*dr̄nó- < *drgh $\left.h_{1}-n o\right)$ др.-инд. dìrnáh 'доля добычи', др.-инд. drṇáti 'birst, macht bersten, sprengt, zerreißt', part. dìrná-, dárīman- n. 'Zerstörung'; лит. диал. dérti ‘драть, обдирать’. ॥ [Дыбо 1961: 14 (№ 39); IEW: 206-208; ср. Matasović 2009: 90].

К структуре корня: и.-е. корень ${ }^{*} d e r z-/^{*} d r \bar{e}-{ }^{*} d \bar{r}-$ 'schinden, die Haut abziehen, abspalten, spalten' (в ларин-

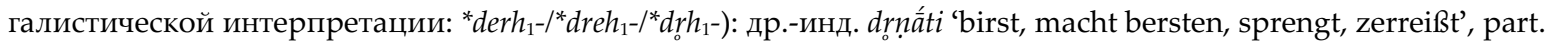
dìrná-, dárìman- n. 'Zerstörung'; лит. dìrti, praes. 1 sg. diriù, praet. 1 sg. dýriau '(zer)reißen, prügeln, schinden, Haut abziehen', диал. dérti 'драть, обдирать, обирать кого, лупить, брать непомерно много’. ॥ [Дыбо 1961: 14 (№ 39); IEW: 206-208; $\operatorname{LIV}_{2}$ : 119-120 ( ${ }^{*} d e r-$ 'zerreißen (intr.), zerspringen')].

2. кельт. "starno- 'pavement' (< ${ }^{*}$ str̄nó-) др.-инд. part. stīrná- 'ausgebreitet, hingestreut', strnậti 'breitet aus, streut', stárī-man- ${ }^{\stackrel{ \pm}{*}}$ Ausbreitung, Ausstreuung'. ॥ [Matasović 2009: 354; KEWA III: 517-518; IEW: 1029-1030].

К структуре корня: и.-е. корень *sterz-/*str̄-/*strē- 'ausbreiten, ausstreuen' (в ларингалистической интерпретации: ${ }^{*} s t e r h_{1}-{ }^{*}{ }^{*} t r h_{1}-{ }^{*}{ }^{s} t r e h_{1}-$ 'ausbreiten, ausstreuen'): др.-инд. (позиция рассечения: тест 9 класса): strnááti 
'breitet aus, streut', полная ступень первой основы: stárī-man- 'Ausbreitung, Ausstreuung'; нулевая ступень в таутосиллабической позиции: др.-инд. part. stīrná- 'ausgebreitet, hingestreut', кельт. *starno- 'pavement'

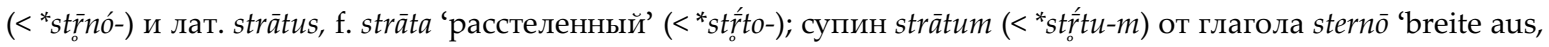
breite hin, streue hin, lege nieder, lagere; ebne, glätte; bedecke, bestreue'; при подобной же двойственности акцентуационной валентности в балтославянском: др.-русск. sg. f. просте́рта [Цв. 72б], pl. просте́рты [Цв. 57б]; l-part. f. нє просте́рласл [Увар. 534б], т. просте́рлъ [Цв. III-43]; при редких следах а. п. $b$ в презенсе: 3 sg. про́стрєть [Сенн. 194г] ([Зализняк 2011, II: 106]); совр. русск. простёрт, простёрта, ср. также лит. stìrta (1), лтш. stir̃ta 'скирда'"; но др.-инд. stīrnáh и приводившиеся мной еще раньше южнославянские материалы:

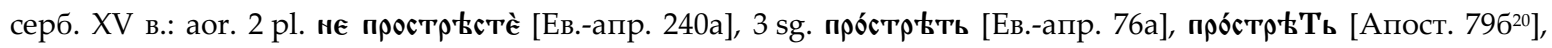

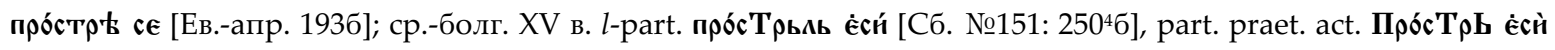
[Сб. №151: 29025б]; хорват. XVII в. aor. 2-3 sg. óbztre nyé [Petr. 165] ([Дыбо 2000: 490, 501]), равно как и др.-русск. part. praet. act. nom. sg. простеє [Чуд. 171] ([Дыбо 2000: 514; Зализняк 2011, II: 106]) и вариант а. п. с у А. А. Зализняка: praes. 1 sg. про́стр8 [Тар. 82], 3 sg. простре́ть [Новг. 227 etc.], 2.pl. прострєтѐ [Постн. 97]; l-part. распростерла́сл [Хлуд. 129], распростерли́сл [Хлуд. 129б] ([Зализняк 2011: 106]). ॥| [WН II: 590-591; KEWA III: 517-518; IEW: 1029-1030]; эта двойственность, согласно выдвинутой мной тональной гипотезе, связана с нисходящим тоном корневой морфемы в тональной системе с регистровыми тонами (см. соответствующие материалы в моих работах по акцентологии сахарских языков).

3. кельт. bar-no- 'Richter', 'Urteil', 'judgement' (< ‘bhr̄-nó-); др.-инд. bharīman- m. 'Erhaltung, Ernährung, Nahrung', bharítra- n. 'Arm', als 'der trågende'. ॥ [McCone 1991: 12; Pedersen 1908-1913. I: 51; Grassmann 1976: 929; Fraenkel 1962-1965: 40; IEW: 128-132].

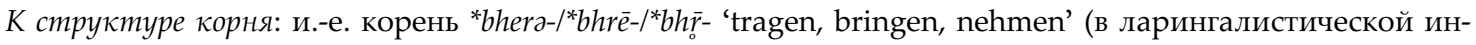

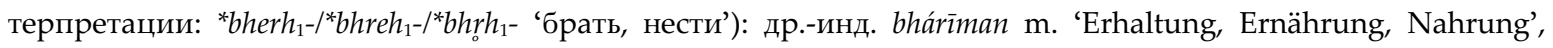

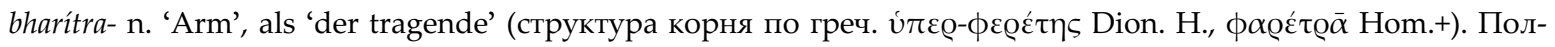

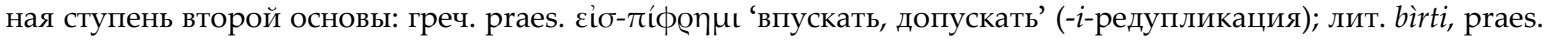
3 sg. bìrsta (intr.) 'streuen, ausfallen, verstreut, zerstückelt werden, zerbröckeln'; лтш. bẽrt [ber̃t Ruj., Salis] (tr.), 'schütten, streuen (vom Getreide, Sand, Asche, Salz u. Ähnlichem)', лтш. bir̃t, praes. 1 sg. bir̃stu, praet. 1 sg. biru (intr.) 'streuen, aus-, abfallen, rieseln, fliessen (von Tränen)', супин bir̃tu (< ‘bh⿳亠丷厂́tum). Двойственность валентности корневой морфемы, отраженная в кельт. bar-no- 'Richter' и *brāthu- 'judgement', достаточно надежно отражается и в балтославянском, что интерпретируется как первичный нисходящий тон корня. ॥ [Irslinger 2002: 86-87; Stokes 1894: 168f.; Pedersen 1908-1913 I: 115; Mühl.-Endz.: 291-292; Karulis 2001: 122; IEW: 130 ( ${ }^{*}$ bhera-/bhrē- 'tragen, bringen'); $\operatorname{LIV}_{2}: 76\left(\sqrt{ } * b^{h} e r\right.$ - 'tragen, bringen')].

4. кельт. *lono- 'Hammel, Schöps', 'баран (холощеный)' (< *lūnó-) др.-инд. lūná- 'abgeschnitten, geschnitten', part. praet. pass. от lunáti, lunốti 'schneidet, schneidet ab', lavítra- n.

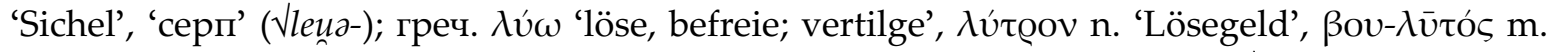

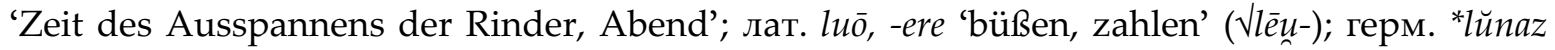
'Lösegeld' (< *lūná- < *lūnó-). ॥ [KEWA III: 106-107; Feist 1939: 338; Orel 2003: 251; Дыбо 1961: 24; Дыбо 2008: 562, 566; IEW: 681-682, 962].

К структуре корня: и.-е. корень *lēuд-/*lu- 'abschneiden, trennen, loslösen; geschnitten' (в ларингалистической интерпретации: *leh $\left.u H_{-} /{ }^{*} l h_{1} u H-\right)$, позиция рассечения - тест 9 класса: др.-инд. lunáti, lunốti 'schneidet,

1 Таким образом, приводимые мной южнославянские материалы [Дыбо 2000: 490, 501], равно как и др.-русск. part. praet. act. nom. sg. просттер [Чуд. 171] ([Дыбо 2000: 514; Зализняк 2011, II: 106]) и вариант а. п. с у А. А. Зализняка, - эта генеративизация а. п. с является, по-видимому, результатом победы диалектной инновации, связанной со спецификой отображения нисходящего индоевропейского тона в акцентной сис-

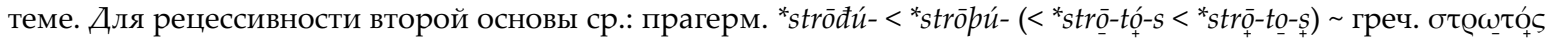
part. praet. pass. (< $\left.{ }^{*} s t r \underline{0}-t \underline{+}-s<{ }^{*} s t r \underline{+}-t \underline{+}-s<{ }^{*} s t r \underline{+}-t \underline{-}-\underline{+}\right)$. 
schneidet ab’; нулевая ступень в таутосиллабической позиции: part. lūná- 'abgeschnitten, geschnitten’; полная

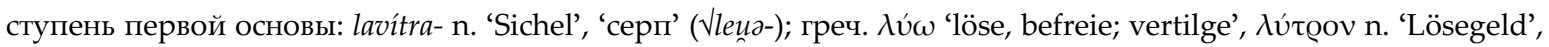

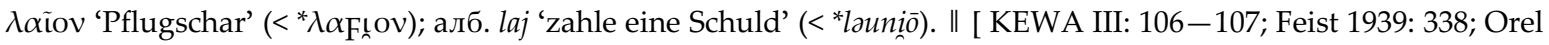
2003: 251; Дыбо 1961: 24; Дыбо 2008: 562, 566; Fraenkel 1962-1965: 363a; Karulis 2001: 552; IEW: 681 -682 (V*leu/*leид- и ل`lēu-/*lau- 'abschneiden, trennen, loslösen'), 962; LIV $2: 417$ (ฟ*leunH- 'abschneiden, lösen')].

5. кельт. *drŭ-na- 'fest' (<*drū-nó-): [др.-ирл. dron 'fest'; cp. gallorom. drūtos 'kräftig, üppig', 'сильный']; герм. “trūēnan 'trauen', 'верить, доверять(ся); вверять': [гот. trauen; др.-исл. trūa; др.-англ. trūwian; др.-фриз. trī̄wa, trōwa; др.-сакс. $\operatorname{trūōn;~др.-в.-нем.~} \operatorname{tru}(w) \bar{e} n$ 'trauen'], герм. *trewwu- 'treu': [гот. triggws adj. 'treu, zuverlässig'; др.-исл. tryggr; др.-англ. ze-trȳwe, зеtrēowe; др.-вост.-фриз. triūwe, др.-зап.-фриз. trouwe; др.-сакс. triuwi; др.-в.-нем. gi-triuwi 'treu']; лит. drútas (3), диал. drúktas (3) 'dick, fest, stark', 'толстый, крепкий, сильный', drūtã̃ 'крепко, сильно'; лтш. drûkts; прус. drüktai 'крепко'.

К структуре корня: и.-е. корень *drēu-/*drū- 'быть крепким, надежным' (в ларингалистической интерпретации: *dreh $h_{1} u$ - ${ }^{*} d r h_{1} u$-): лит. drútas (3), диал. drúktas (3) 'dick, fest, stark', 'толстый, крепкий, сильный', drūtã̃ 'крепко, сильно'; лтш. drûkts; прус. drũktai 'крепко'; акцентовка литовских основ и латышская прерывистая интонация свидетельствуют о рецессивной валентности корневой морфемы, об отклонении в прусском см. [Дыбо 2009: 153]. ॥ [Feist 1939: 479-480, 480; Orel 2003: 411, 410; Fraenkel 1962-1965: 107; IEW: $214-$ 217 (фактически лишь 216-217)].

\section{В. Кельто-италийские баритона. -to-основы:}

1. кельт. *bìto- (<*bhịtto-): ирл. bith (в praet. pass. ro-bíth, от Vr. др.-ирл. benaid 'schlägt')

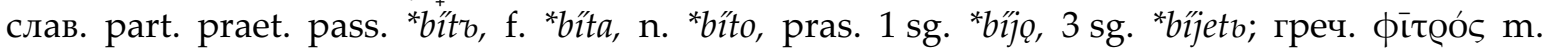
'Baumstamm, Holzscheit', фīuós m. 'Knebel, Maulkorb'. ॥ [Matasović 2009: 65-66; De Bernardo Stempel 1999: 442; Irslinger 2002: 431; Isaac 2007: 27 (ошибочно: < “bhih2-tó-)].

К структуре корня: и.-е. корень ${ }^{* *} b h e i \partial-/{ }^{*} b h \bar{\imath}$ 'schlagen' (в ларингалистической интерпретации: **bheiH/*bhiH-): слав. part. praet. pass. *bîtb, f. *bîta, n. *bîto, русск. om-бúm, за-бúm, n. om-бúmo, за-бúmo, f. бúma, om-бúma,

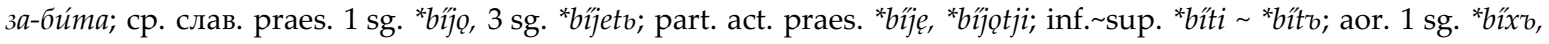

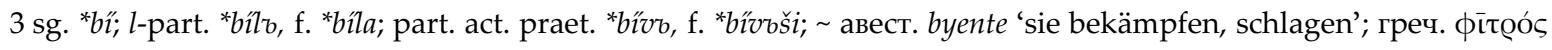

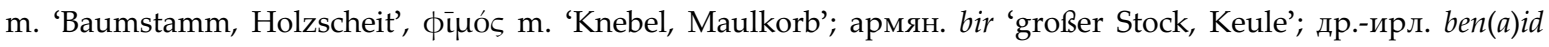
'schlägt', ro-bīth 'wurde geschlagen', bīthe 'geschlagen'. Славянский материал указывает на доминантную валентность этого глагольного корня. ॥ [Дыбо 1961: 15, 19, 31-32; IEW: 117-118 (لbhei(a)-/bhī- 'schlagen'); LIV $72\left(\sqrt{ } * b^{h} e i H\right.$ - 'schlagen')].

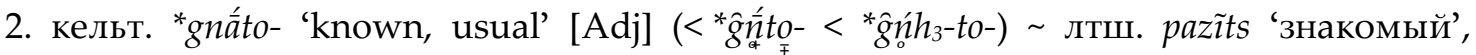
др.-в.-нем. kund, гот. kunps 'знакомый, известный'. ॥| [Matasović 2009: 162; WH I: 614, Isaac

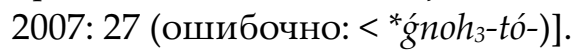

К структуре корня: см. под А. -to-основы, 5, др.-лат. *gnŏtus; лабильность корня по отношению к валентности, согласно тоновой интерпретации, должна, по-видимому, раскрываться как первично нисходящий тон корневой морфемы.

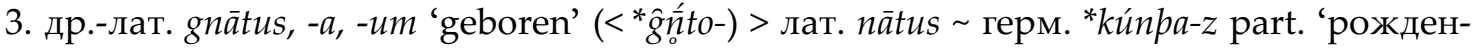
ный'. Относительно доминантности корня ср. также лит. žéntas (1) 'зять' и лтш. znuо̃ts 'Schwiegersohn; Schwager, Schwestermann'. ॥ [Barber 1932: 118, 130; Heidermanns 1993: 347; Egilsson: 350, 7, 31, 460; IEW: 373-375; Orel 2003: 223; Frisk 1960-1972 I: 306-308; WH I: 597-600; Дыбо 1961: 9-34; Дыбо 2007]. 


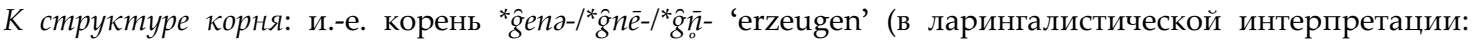

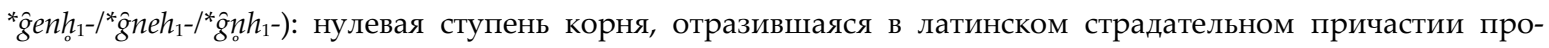
шедшего времени, хорошо представлена в германском: герм. *kúnpa-z part. 'рожденный’ [др.-исл. -kunnr в др.-исл. alf-kunnr adj. 'af alve-herkomst', ás-kunnr adj. 'oprunden af aserne, af gude-herkomst; богорожденный', regin-kunnr adj. 'fra guderne stammende, om runerne'; др.-в.-нем. aD gomman-kund 'männlich', MF man-kund 'männlich', T, BR, aD, Ab got-kund 'göttlich'; и в гот. ga-kunps 'Geburt' (только в uf gakunpai [Luc. 3:23], греч.

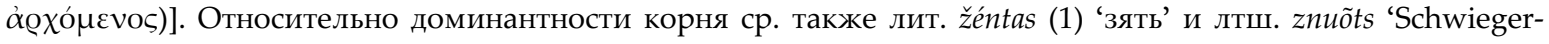

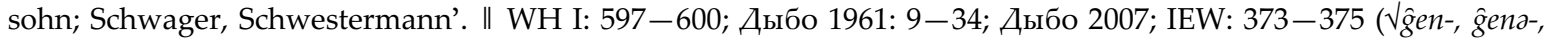

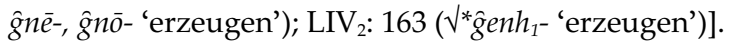

4. кельт. *-gníto- 'порожденный, сотворенный’ (<*-gnętto-) part. praet. pass. conjunct. oт др.-ирл. praes. 1 sg. gnīu 'ich mache, tue' лит. žéntas (1) 'зять'; лтш. znио̃ts 'Schwiegersohn; Schwager, Schwestermann'. II [Thurneysen 1980: 438; Matasović 2009: 163-164; Fraenkel

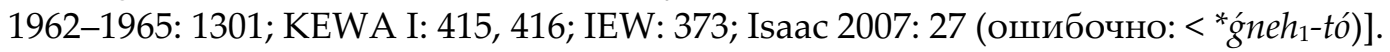

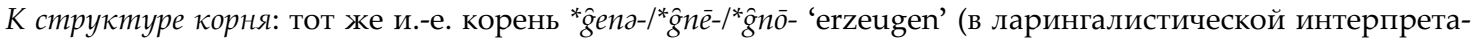
ции: * $\left.\hat{g} e n h_{1}{ }^{*} / \hat{g} n e h_{1} /{ }^{*} \hat{g} n o h_{1}-\right)$ : корень представлен в кельтском в полной ступени второй основы. В отличие от корня * gैena-/*ghne-/*ôno- ‘erkennen, kennen', этот корень показывает доминантность во всех формах (ступенях аблаута) и, следовательно, имеет высокий тон, о чем свидетельствуют балтийские примеры: лит. žéntas (1)

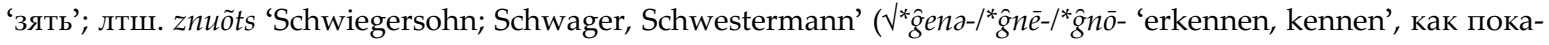
зано выше, имел, вероятно, нисходящий тон). ॥ [Thurneysen 1980: 438; Matasović 2009: 163-164; Fraenkel

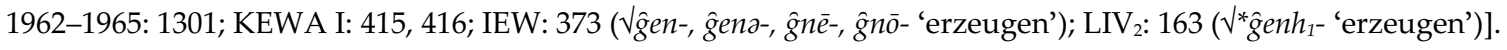

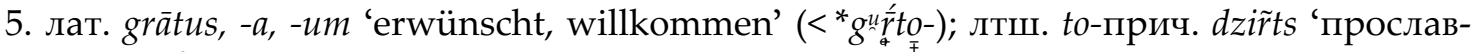

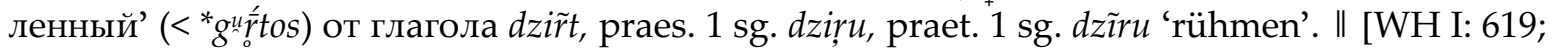
Mühl.-Endz. I: 555; Karulis 2001: 257].

К структуре корня: и.-е. корень ${ }^{*} g^{u} e r{ }^{\prime}{ }^{*} g^{\prime}{ }^{u} \bar{g}-$ 'loben, preisen, willkommen heißen' (в ларингалистической интерпретации: * $\left.g^{u} e r H-{ }^{*} g^{u} r H-\right)$ : др.-инд. ведийск. grnáti 'begrüßt, rühmt', part. praet. pass. gūrtáh 'приятный, желанный'; доминантную валентность корневой морфемы показывает латышский: лтш. to-прич. dzir̃ts

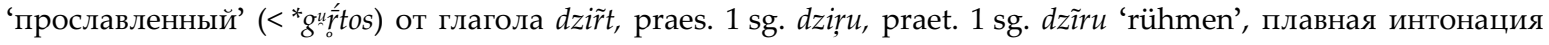
свидетельствует о неподвижной акцентной парадигме с накоренным ударением (доминантная валентность корневой морфемы); показание латышского подтверждает и старославянский: страдательное причастие пожъреныи [Супр. 46012] является закономерной заменой баритонированного -to-part. с накоренным ударением. Процесс замены баритонированных -to-part. на -en-part. происходил, по-видимому, во всех южнославянских языках, но следы старого состояния иногда обнаруживаются в среднеболгарских рукописях юговосточной локализации написания (точнее, конечно, говора писца). Основы баритонированных -to-part. coхраняются в именных образованиях (существительных): жрътига [Супр. 14830]. Латинский рефлекс хорошо согласуется с балтославянским акцентным типом, но рефлекс кельтской презентной основы указывает на окситонезу. II [WH I: 619; Mühl.-Endz. I: 555; Karulis 2001: 257; Meyer 1935: 178-179, 78; IEW: 478 ( $\sqrt{*}^{*} g^{u} e r a-/^{*} g^{u} \bar{r}^{u}-$ 'die Stimme erheben', ‘loben, preisen, willkommen heißen'); $\mathrm{LIV}_{2}: 210-211\left(\sqrt{ }^{*} \mathrm{~g}^{u} \mathrm{erH}-\right.$ 'Zustimmung bekunden')].

6. кельт. $k^{w} r \bar{i} t o-$ 'куплен' (<* $\left.k^{w} r_{+}^{\frac{1}{1}-t o-}<{ }^{*} k^{w} r_{+} h_{2}-t o-\right)$; др.-русск. крьнути 'купить', praes. $3 \mathrm{sg}$. крьнеть, part. praet. pass. укриень 'купленный', который свидетельствует о баритонезе восстанавливаемой праславянской формы *krítos (в ст.-слав. языке баритонированные причастия на -tos были заменены причастиями на -еnos; о существовании ранее в славянском причастия на -tos от этого глагола свидетельствует производное от этого причастия существительное: по критии 'по искуплении' [Усп. сб. 207в14-15]) и, соответственно, о неподвижной баритонированной акцентной парадигме данного праславянского глагола. ॥

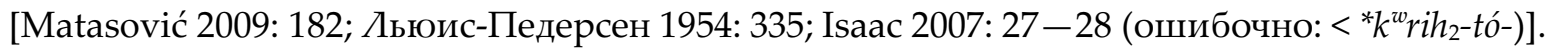


К структуре корня: и.-е. корень ${ }^{*} k^{u} r e i a-{ }^{*}{ }^{u}{ }^{u} r \bar{i}-$ 'kaufen’ (в ларингалистической интерпретации: ${ }^{*} k^{u} r e i h_{2}-$

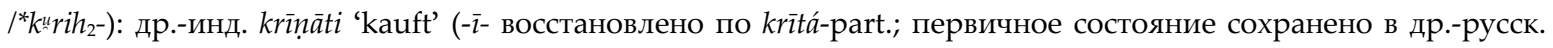
крьнути 'купить, взять': praes. 3 sg. крьнеть). Доминантность корня устанавливается по форме слав. раrt. praet. pass. I| [Matasović 2009: 182; Льюис-Педерсен 1954: 335; Фасмер II: 371-372; IEW: 648 ( ${ }^{*} k^{\prime \prime}$ rei- 'kaufen’); $\mathrm{LIV}_{2}: 395-396$ ( ${ }^{*} k^{*}$ rei $h_{2^{-}}$'eintausch, durch Tausch erwerben')].

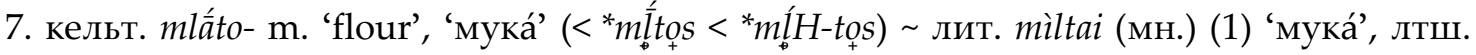
mî̃ti (мн.) 'мука́'; др.-инд. mrṇāti 'zermalmt, mahlt', part. praet. pass. mūrná- 'размолотый'; слав. praes. $1 \mathrm{sg}$. *meljö, 3 sg. *mèljets (а. п. b) лтш. maît 'mahlen'. ॥I [Matasović 2009: 273274; Дыбо 1961: 18; KEWA II: 698-699; IEW: 716-717; De Bernardo Stempel 1987: 130 (ошибочно: < *mlH-tó- 'gemahlen')].

К структуре корня: и.-е. корень *mela-/*mle--/*ml- 'zermalmen, schlagen, mahlen' (в ларингалистической

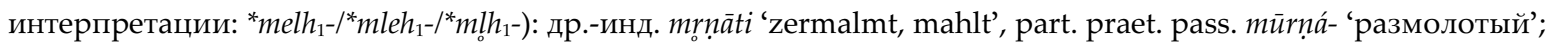

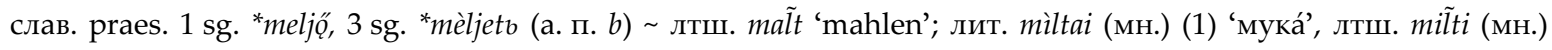
'мука́', плавная интонация в латышском и неподвижные а. п. в литовском и славянском указывают на доминантность корневой морфемы. ॥ Matasović 2009: 273-274; Дыбо 1961: 18; KEWA II: 698-699; De Bernardo Stempel 1987: 130 (ошибочно: < *mlH-tó- 'gemahlen'); IEW: $716-718$ ( $\left({ }^{*} m e l ə-{ }^{*} m l \bar{e}-{ }^{*} m_{\circ} \bar{l}-\right.$ 'zermalmen, schlagen, mahlen'); $\mathrm{LIV}_{2}$ : 432 ( ${ }^{*}{ }^{*}$ elh $2^{-}$zerreiben, mahlen’)].

8. лат. pūto- (<*púțo- в pūtēre 'гнить') лит. púti 'faulen, modern'; лтш. pũt, praes. $1 \mathrm{sg}$. pũstu, praet. $1 \mathrm{sg}$. puvu 'faulen, modern, lange schlafen'. II [WH II: 393; KEWA II: 322; Fraenkel 1962-1965 II: 680-681; Дыбо 1963: 31].

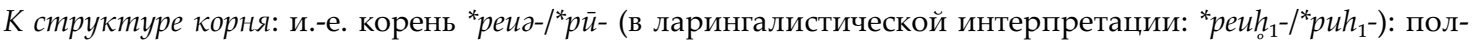
ная ступень в авест. paviti- f. 'Fäulnis, Verwesung' [Bartholomae 1904: 849] и в лит. piáulas 'verfaultes, morsches Holz', pl. piaulaĩ 'Sägespäne'; лтш. praûls 'moderndes, vermodertes Stück Holz' (значение лит. рl. указывает на контаминацию с корнем *piāu- 'толочь, резать, пилить', см. [IEW: 827] *pēu-, лтш. praûls из *plaûls в результате диссимиляции); -о-ступень: др.-исл. feyja 'verfaulen lassen' < * роиәјо-; нулевая ступень: др.-инд. pú yati ‘wird faul, stinkt', púuyah m., -am n. 'Eiterung, Ausfluß, Eiter', pútih 'faul, stinkend'; авест. pūiti f. 'Fäulnis, Verwesung' [Bartholomae 1904: 909]; греч. тúv $\omega^{\prime}$ 'mache faulen'; лат. pūteō, pūtēscō 'faule'; нулевая ступень в гетеросиллаби-

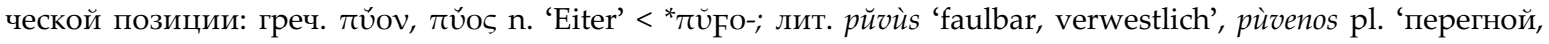
гумус', лит. púti 'faulen, modern'; лтш. pũt, praes. 1 sg. pũstu 'faulen, modern, lange schlafen', плавная интонация указывает на неподвижную а. п. и, следовательно, на доминантность корневой морфемы. ॥ [KEWA II:

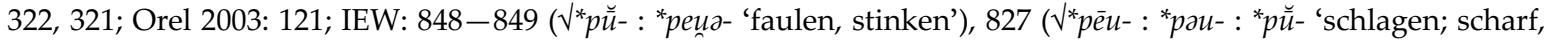

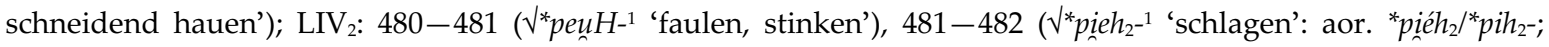
praes. * piéh $h_{2}-u-/{ }^{*}$ pih $_{2}-u-$ лит. piáuju, лтш. pḷaũt).

9. лат. rūto- (< ${ }^{*}$ rúto- в rūta pl. от *rūtum), part. praet. pass. от ruō, rū, rūtus, -ere 'wühle, scharre'; др.-исл. rȳja 'den Schafen die Wolle ausreißen' слав. praes. 1 sg., “rýjo, 3 sg. * rýjetb; to-part. ry̆tı, f. rÿta, n. rÿto. II [WH II: 453-454; Дыбо 2000: 228, 278, 497, 510, 522, 542].

К структуре корня: и.-е. корень *rāu-/*rau- (в ларингалистической интерпретации: *reh $h_{2} u-/{ }^{*} r h_{2} u$-): полная ступень в гетеросиллабической позиции в лит. rovà 'nach einer Überschwemmung auf einer Wiese zurückgelassenes Geschiebe’; лтш. rãva Līn., Selg., Wandsen, Dond., Kandau, Kurs., Arrasch, Ruj. *Rückstand nach Überschwemmung auf Wiesen' $\Rightarrow$ 'stinkendes, eisenhaltiges Wasser, eine solches Wasser enthaltende sumpfige Stelle'; нулевая ступень в таутосиллабической позиции в лат. rūta f. 'вырытое', rŭ trum n. 'заступ, лопата', в современных романских языках отражается только краткостный вариант, см. [Meyer-Lübke 1935: 618]; нулевая ступень в гетеросиллабической позиции: слав. * rövъ, gen. sg. *ròva > *rová < * roú- (русск. диал. poв, gen. sg. ро́ва, укр. галицк. сан. Черн. riow, gen. rọvá, róva, pl. rọvý, покут. Печ. r’iw, gen. rọvá, pl. rọvạ́ - а. п. d; подольск. pis, gen. sg. ровá; схрв. литер. pôв, gen. sg. рӧва - а. п. $d$ или с, диал. Ю. Бараня rõv, gen. *ròva 382, 451, instr. 
*rovõm, pl. *rovövi 382 - а. п. b; а. п. $b$ и d, см. [ОСА (Словарь): 267-269]); лит. rãvas 'Straßengraben'. Этот корень не удается отделить от корня, представленного в лат. rŭtuт и подобных, поэтому приходится считаться с его лабильностью по отношению к валентности и интерпретировать его как имевший нисходящий тон.

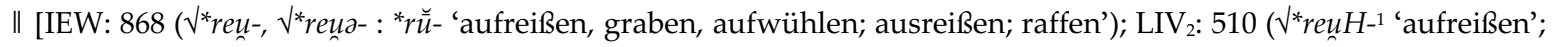
(?) *ruH-ié- : an. rýja 'Wolle abreißen'; др.-ц.-слав. ryjo (ryti) 'graben’)].

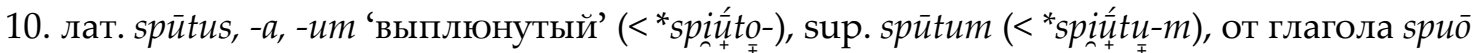
'spucke'; др.-инд. șthí̀vati 'spuckt, speit aus' лтш. splaũt, praes. 1 sg. splaũju, супин spl̨aũtu, topart. splaãts ‘выплюнутый’; русск. плева́mь, praes. 1 sg. плю́ю, 3 sg. плю́ет. \|I [WH II: 580-581].

К структуре корня: и.-е. корень *spiāu-/*spiū- (в ларингалистической интерпретации: *spieh $\left.{ }_{2} u-/{ }_{n}^{*} s p i h_{2} u-\right)$ : полная ступень в лит. spiốva 'плевака', 'Spucker-(in)', spiōvimas 'плевание', 'Spucken, Speien’; лтш. spḷãviêns 'das einmalige Speien'; -о-ступень, возможно, в авест. spāma- 'Speichel, Schleim' (< *spiōmo- < *spiōumo-, с потерей глайда в долгом дифтонге); нулевая ступень: др.-инд. șthyūtá- 'gespuckt, gespien’; лат. spūtum n. 'плевок’; также в презентных основах: греч. $\pi \tau \hat{v} \omega$ 'spucke'; лат. spū̄; герм. *spüja- (др.-исл. spýja; вост.-фриз. spüjen 'spucken, sprühen', ср.-нидерл. spuwen 'spucken, speien'); нулевая ступень в гетеросиллабической позиции: др.-инд. șțhīvati 'spuckt, speit aus'; герм. *spīwa- (гот. speiwan; др.-англ. spīwan, др.-сакс. spīwan, др.-в.-нем. spīwan, spīan). Как показывают балтославянские и приводимые в этом разделе германские данные, глагол имел неподвижную баритонированную а. п. и, следовательно, корневая морфема была доминантной. ॥ [IEW: 999-1000

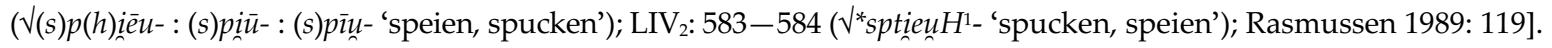

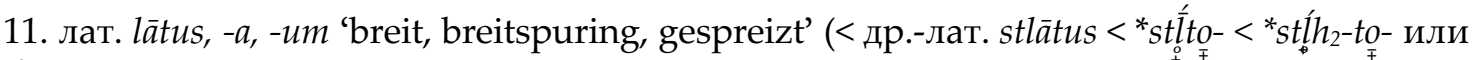

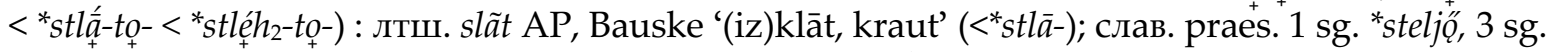
*stèljetr, l-part. *stláltb, f. *stlála; (?) лит. tiltas (1), лтш. tilts 'мост'. ॥| [WH I: 772; Дыбо 2000: 270; Karulis 2001: 850-851, 852; Mühl.-Endz. III: 924].

К структуре корня: и.-е. корень *stela-/*stlā- 'ausbreiten, flach hinbreiten' (в ларингалистической интер-

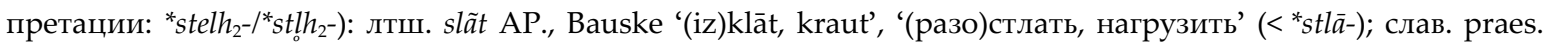
1 sg. *steljő, 3 sg. *stèljetr, l-part. *stlált, f. *stlála (русск. стелю́, сте́лешь, укр. стелю́, сте́леш; словен. stéljem; болг. cтѐля, стѐлищ, с переходом в i-спряжение); (?) лит. tiltas (1), лтш. tiltts 'мост' др.-инд. tīrtá- 'Steig zum Wasser, Furt, Badeplatz'. Балтославянские соответствия указывают на доминантную валентность корневой морфемы. ॥ [WH I: 772; Дыбо 2000: 270; Karulis 2001: 850-851, 852; Mühl.-Endz. III: 924; Fraenkel 1962-1965: 10/94; IEW:

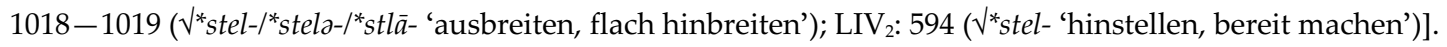

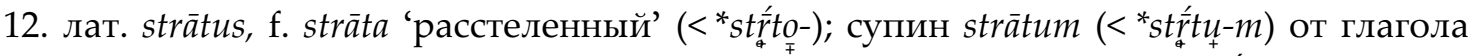
sternō 'breite aus, bedecke, bestreue'; др.-ирл. sernim 'breite aus'; др.-инд. strnáti 'breitet aus, streut', part. praet. pass. stìrnáh 'ausgebreitet, hingestreut', stárīman- n. 'Ausbreitung, Ausstreuung'; эту основу следует отделить от др.-инд. strnóti, stárati 'streckt nieder, unterwirft, besiegt' (ср. [KEWA III: 518]) др.-русск. sg. f. просте́рта [Цв. 72б], pl. просте́рты [Цв. 57б]; l-part. f. не просте́рласл [Увар. 534б], m. просте́рлъ [Цв. III-43]; при редких следах а. п. $b$ в презенсе: 3 sg. про́стреть [Сенн. 194г] ([Зализняк 2011, II: 106]); совр. русск. простёрm, простёрта, ср. также лит. stirta (1), лтш. stir̃ta 'скирда' (см. сноску 1). ॥[ [WH II: 590-591; KEWA III: 517-518; IEW: 1029 - 1030].

К структуре корня: см. под А. -по-основы, 2, кельт. *starno-.

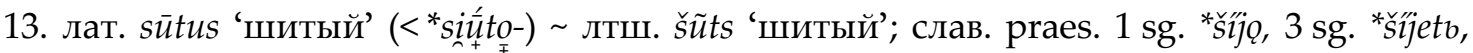
to-part. *šitro, f. *šíta. || [WH II: 631-632; Дыбо 1961: 18; Дыбо 2000: 276, 489, 496, 509, 518-519, 522, 523 (= Дыбо 1981: 221), 542].

К структуре корня: и.-е. корень *siāu-/*sin̄- (в ларингалистической интерпретации: * $\left.\operatorname{sich}_{2} u-/{ }^{*} \operatorname{sih}_{2} u-\right)$ : полная ступень первой основы: др.-инд. sevanam 'das Nähen, die Naht'; полная ступень второй основы: др.-инд. 
syota-, syona- m. 'Sack' (Lex.); нов.-перс. yūn 'Satteldecke' (< ‘hyauna-), - и, возможно, в герм. *siaumaz (др.-исл. saumr m. 'Saum, Naht'; др.-англ. sēam, др.-фриз. sām, ср.-н.-нем. sōm, др.-в.-нем. sоum); нулевая ступень: др.-инд. syūtá- 'genäht'; лат. sūtus; лит. siútas, лтш. šũts, русск. шúm, f. шúma, п. шúmo; др.-инд. sútra-m (AV.)

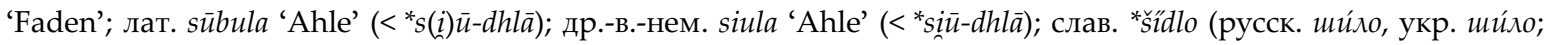
болг. ши́ло, схрв. шйло, словен. šílo; чеш. šídlo, слвц. šidlo, польск. szydło, в.-луж. šidło, н.-луж. šydło, полаб. saidlü); нулевая ступень в гетеросиллабической позиции: др.-инд. sìvana-m 'das Nähen, die Naht', sívoyati 'näht', гот. siujan. Балтославянские и германские данные указывают на доминантность корня. ॥ [WH: 631-632; Holthausen 1934: 296; Orel 2003: 329; Фасмер IV: 438; KEWA III: 477-478; IEW: 915 -916 (ل`siñ- : *sīu- 'nähen'); $\mathrm{LIV}_{2}$ : 545 ( ${ }^{*}$ sieuH-1 'nähen'); Rasmussen 1989: 115-116, 118].

14. лат. trītus, - $a$, -um 'abgerieben, geübt' (< ${ }^{*}$ trì-to-), от лат. terō 'reibe (ab), zerreibe, dresche' лит. trìntas; лтш. trĩts 'тертый'. ॥ [WH II: 672-673; Дыбо 1961: 19; Fraenkel 19621965: 1124-1125, 1102; Дыбо 2000: 263, 330, 481-482, 488, 491, 503, 523; IEW: 1071-1073].

К структуре корня: и.-е. корень *tera-/*trē-/*tr̆-//*trēi-/*trī- 'reiben; drehend reiben; durchbohren' (в ларин-

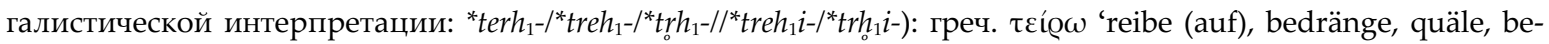

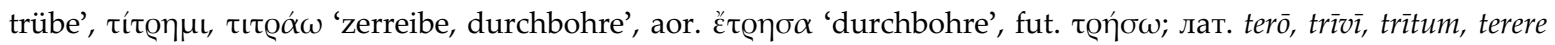
'reibe, reibe ab, zerreibe' лит. trìntas, inf. trìnti, praes. 1 sg. trinù, praet. 1 sg. trýniau '(durch)reiben, feilen'; лтш.

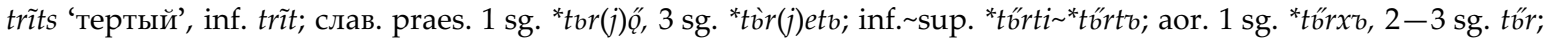

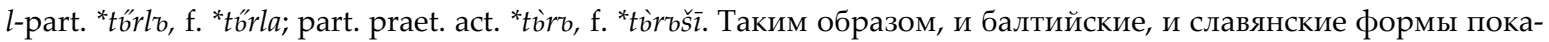
зывают доминантность корневой морфемы. ॥ [WH II: 672-673; Дыбо 1961: 19; Fraenkel 1962-1965: 11241125, 1102; Дыбо 2000: 263, 330, 481-482, 488, 491, 503, 523; IEW: 1071-1073].

15. кельт. * ${ }^{*}$ é-to- или *-rí-to- 'wurde verkauft' (< ${ }^{*} h_{2} r e ́(i)-t o-$ или $\left.<{ }^{*} h_{2} r a i ́-t o-<{ }^{*} h_{2} r h_{1} i-t o-\right) . \|$ [McCone 1991: 37-40; Irslinger 2002: 27-28; Matasović 2009: 313; Isaac 2007: 28 (< ‘ $h_{2}$ riH-tó-)].

К структуре корня: и.-е. корень *әrē(i)- 'geben, schenken', 'zählen, rechnen' (в ларингалистической интерпретации: “h ${ }_{2}$ reh $_{1}(i)$ - 'geben, schenken', 'zählen, rechnen'): лат. reor, ratus sum, rēri 'berechnen, meinen, da-

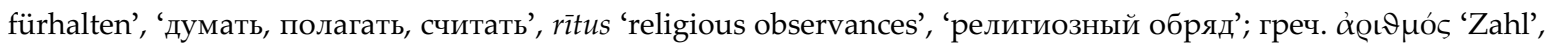
vท̣́ıтоৎ 'ungezählt'. ॥ [McCone 1991: 37-40; Irslinger 2002: 27-28; Matasović 2009: 313; Isaac 2007: 28 (< $h_{2}$ riHtó-); IEW: 59-61, 860; $\mathrm{LIV}_{2}$ : 499].

16. лат. part. praet. pass. lātus $\left(<{ }^{*} t l a \bar{t} t o s<\underset{+}{*}+{ }_{+}^{\hat{I}}-t o-\right)$ 'getragen'. \| [Matasović 2009: 380; IEW: 1060-1061; WH I: 772; II: 688-689].

К структуре корня: и.-е. корень *tela-/*tle( $(i)-{ }^{*}{ }^{*} t \bar{l}-$ 'aufheben, wägen; tragen; ertragen, dulden' (в ларингалистической интерпретации: *telh $\left.{ }^{-}{ }^{*} t l e h_{1^{-}}(i)-{ }^{*} t{ }_{o} h_{1^{-}}\right)$: лат. tollō, -ere (sustuli, sublätum) 'empor, in die Höhe heben' $\left(<{ }^{*} \operatorname{tln} \bar{o}\right.$, перестроено из $\left.{ }^{*} t l-n \bar{a}-m i\right)$, tulī, др.-лат. tetulī, perf. к ferō, др.-лат. conj. tulam 'tragen, bringen', lātus 'getragen'; ср.-ирл. tlenaim 'stehle' (“tınа̄mi), валл. tlawd 'arm' (*'duldend'); лтш. iztilt 'aushalten' [Zb. XVIII, 370] (слоговая интонация не зафиксирована), izstilt², -stilu (Livvāni) od. -stilstu² (Pilda), -stilu, = iztilt 'aushalten' (по-видимому, -il- <*-iٓ-, ввиду совпадения в восточных латышских диалектах плавной и нисходящей интонаций в нисходящей). ॥ [Mühl.-Endz. I: 818; IEW: 1060-1061 (ฟtel-1, telo-, tlē(i)-, tlā-); LIV 2 : 622 ( ${ }^{*}$ telh $_{2}$ ' 'aufheben, auf sich nehmen')].

\section{-tu-основы:}

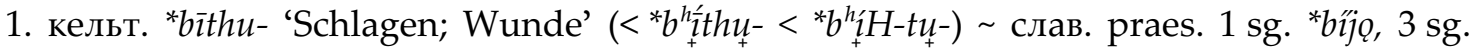
*bijetb; sup. *bîtb; part. praet. pass. *bîtr, f. *bíta, n. *bíto. II [Matasović 2009: 65-66; De Bernardo Stempel 1999: 442; Irslinger 2002: 29, 431; Isaac 2007: 27 (ошибочно: < *bhih2-tó-)].

К структуре корня: см. под В. --о-основы, 1, кельт. *bīto-.

2. кельт. *bräthu- 'judgement' (<*bhrítu-) лит. bìrti, praes. 3 sg. bìrsta intr. 'streuen, ausfallen, verstreut, zerstückelt werden, zerb̆öokeln'; лтш. bẽrt [ber̃t Ruj., Salis] (tr.), 'schütten, 
streuen (vom Getreide, Sand, Asche, Salz u. Ähnlichem)', лтш. biřrt, praes. 1 sg. biřstu, praet. 1 sg. biru (intr.) 'streuen, aus-, abfallen, rieseln, fliessen (von Tränen)', супин biŕtu (<*bhŕrtum). || [Irslinger 2002: 86-87; Stokes 1894: 168f.; Pedersen 1908-1913 I: 115; Mühl.-Endz.: 291-292; Karulis 2001: 122; IEW: 130; $\operatorname{LIV}_{2}$ : 61f.].

К структуре корня: см. под А. -по-основы, 3, кельт. *bar-no-.

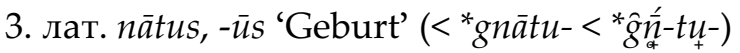

К структуре корня: см. под В. -to-основы, 4, др.-лат. gnātus.

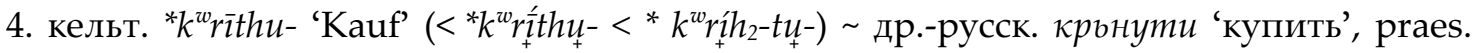
3 sg. крьнеть, part. praet. pass. укриень 'купленный', который свидетельствует о баритонезе праславянской формы *krítos (в ст.-слав. языке баритонированные причастия на -tos были заменены причастиями на -enos); о существовании в славянском причастия на -tos свидетельствует производное от него существительное: по | критии 'по искуплении' [Усп. сб. 207в $14-15]$ || [Irslinger 2002: 29; Matasović 2009: 182; Дьюис-Педерсен 1954: 335; Isaac 2007: 27-28 (ошибочно: < $\left.\left.{ }^{*}{ }^{w} r i h_{2}-t o ́-\right)\right]$.

К структуре корня: см. под В. -to-основы, 6, кельт. $k^{w} r i \bar{t} о-$.

5. лат. spūtum (<*spiútu-m), супин от глагола spuō 'spucke'; др.-инд. șthítvati 'spuckt, speit aus'; греч. $\pi \tau \hat{v} \omega$ 'spucke' лтш. spḷaũt, praes. $1 \mathrm{sg}$. spḷaũju, sup. spḷaũtu, to-part. splaũts 'выплюнутый'; русск. плева́ть, praes. 1 sg. плю́ю, 3 sg. плю́ет. ॥ [WH II: 580-581].

К структуре корня: см. под В. -tо-основы, 10, лат. spūtus.

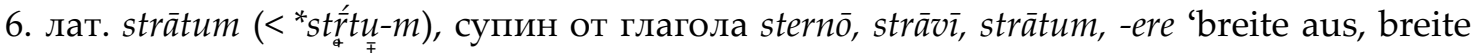
hin, streue hin, lege nieder, lagere; ebne, glätte; bedecke, bestreue'; др.-ирл. sernim 'breite aus'; др.-инд. strnáti 'breitet aus, streut', part. praet. pass. stìrnáh 'ausgebreitet, hingestreut', stárimman- n. 'Ausbreitung, Ausstreuung'; эту основу следует отделить от др.-инд. strnōti, stárati 'streckt nieder, unterwirft, besiegt' (cp. [KEWA III: 518]) др.-русск. sg. f. просте́рта [Цв. 72б], pl. просте́рты [Цв. 57б]; l-part. f. не просте́рласл [Увар. 534б], m. просте́рлъ [Цв. III-43]; при редких следах а. п. $b$ в презенсе: 3 sg. про́стрєть [Сенн. 194г] ([Зализняк 2011, II: 106]); совр. русск. простёрm, простёрта, ср. также лит. stìrta (1), лтш. stir̃ta 'скирда' (см. сноску 1). ॥| [WH II: 590-591; KEWA III: 517-518; IEW: 1029-1030].

К структуре корня: см. под А. -по-основы, 2, кельт. *starno-.

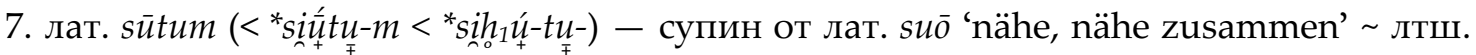

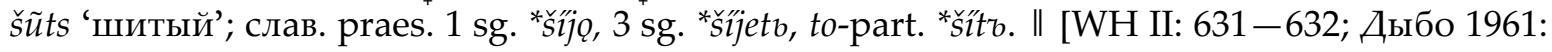
18; Дыбо 2000: 276, 489, 496, 509, 518-519, 522, 523 (= Дыбо 1981: 221), 542].

К структуре корня: см. под В. -to-основы, 13, лат. sūtus.

8. лат. trītum (<*trí-tu-) - супин от лат. terō 'reibe (ab), zerreibe, dresche' лит. trìntas, inf. trìti, praes. $1 \mathrm{sg}$. trinù, praet. $1 \mathrm{sg}$. trýniau '(durch)reiben, feilen'; лтш. trĩts 'тертый'. ॥ [WH II: 672-673; Дыбо 1961: 19; Fraenkel 1962-1965: 1124-1125, 1102; Дыбо 2000: 263, 330, 481-482, 488, 491, 503, 523; IEW: 1071-1073].

К структуре корня: см. под В. -to-основы, 14, лат. trītus.

\section{-по-основы:}

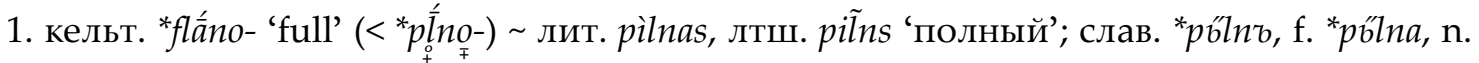
*púlno; афг. pán, f. pána ‘полный, наполненый’. ॥ [Дыбо 1961: 18; Дыбо 1974: 76]. 
К структуре корня: и.-е. корень *pela-/*ple-/*pl- 'gießen, fließen, aufschütten, füllen, einfüllen' (в ларингалистической интерпретации: * pelh $^{-{ }^{*}}{ }^{*} p l e h_{1}{ }^{*}{ }^{*} l_{o} h_{1-}$ ): др.-инд. prnáti (prṇáti) 'füllt, sättigt, nährt, spendet reichlich, beschenkt', также prṇóti то же, púrryatē 'füllt sich', aor. áprāt (: $\pi \lambda \tilde{\eta} \tau о)$, perf. paprāu (: лат. plēvī), part. prātá- (= лат. plètus), pūrtá- 'voll', prāna- 'voll' (= лат. plēnus), pūrná- 'voll', др.-лит. pìlnas (1, следы первоначальной баритонезы обнаруживаются у Донелайтиса и у Даукши), лтш. piins (плавная интонация указывает на первоначальную баритонезу); но др.-инд. párīman- 'Fülle' долготой -ī- указывает на рецессивную валентность корневой морфемы, на это же указывает и лтш. pilt 'tröpfeln'. Такая двойственность выбора морфемой валентности, свидетельствует, как показано выше, о нисходящем тоне морфемы. ॥ [Дыбо 1961: 18; Дыбо 1974: 76; IEW:

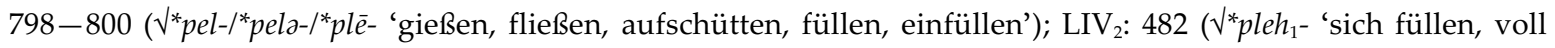
werden')].

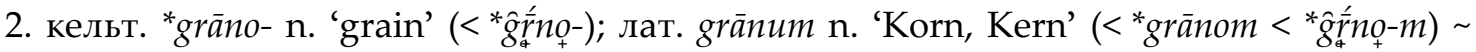
слав. *zb̆́rno n. 'Korn', pl. *zb̈rna. ॥ [WH I: 618-619].

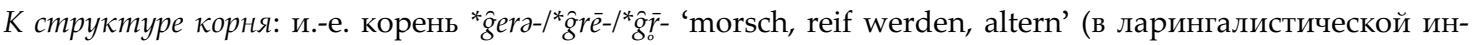

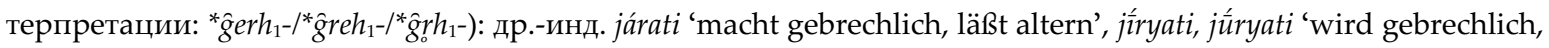
morsch, altert', part. jūrná-, jìrná- 'gebrechlich, abgelebt, abgenutzt, zerfallen, morsch, alt'; слав. *zórno n. 'Korn', pl. *zb́rna. Доминантность корня показывают славянские данные. ll [Дыбо 1961: 18; Дыбо 1974: 76; IEW: 390-

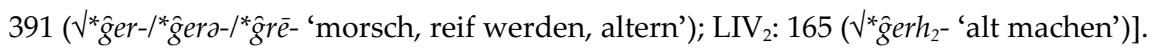

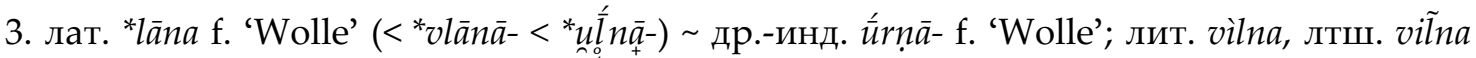
'Wolle'; слав. *vb́lna f. 'Wolle'. ॥ [WH I: 756-757; Fraenkel 1962-1965: 1253-1254; Фасмер I: 339-340; Orel 2003: 474].

К структуре корня: и.-е. корень “uela-/“ūl- в словах для значений 'волос' и 'шерсть', возможно, от $\sqrt{*} u e l-$

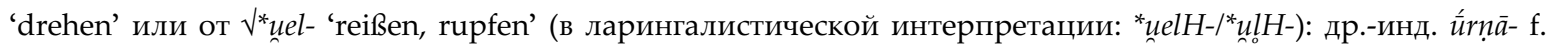
'Wolle’, ‘шерсть'; авест. varnā f. 'Wolle’; герм. *wullō f. [гот. wulla; др.-исл. ull; др.-англ. wull; ср.-н.-нем. wulle; др.-в.-нем. wolla 'Wolle']; лит. vilna 'Wollhärchen', лтш. vilna 'Wolle'; слав. *vólna, f. 'Wolle' [русск. во́лна, укр. во́вна, блр. f во́ўна; болг. въ́лна, схрв. вйна; словен. vółna; чеш. vlna, слвц. vlna; польск. wetna]. Балтославянские соответствия показывают накоренное удорение и, следовательно, доминантную валентность корневой морфемы. II [WH I: 756-757; Fraenkel 1962-1965: 1253-1254; Фасмер I: 339-340; Orel 2003: 474; IEW: 11391145; LIV $: 675$ (ฟ*uel- ‘drehen, rollen’), 677 (ฟ*uelH- ‘(sich) wälzen, wallen’)].

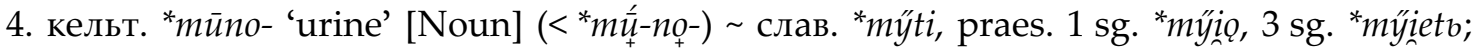

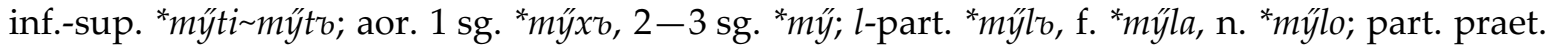
act. *mÿvrb, f. *mývršì. ॥| [Matasović 2009: 281; KEWA II: 663-664; Дыбо 2000: 277-278, 307, 310, 330-331, 489, 496, 510, 517; IEW: 741-742].

К структуре корня: см. под А. - -о-основы, 14, кельт. *muto-.

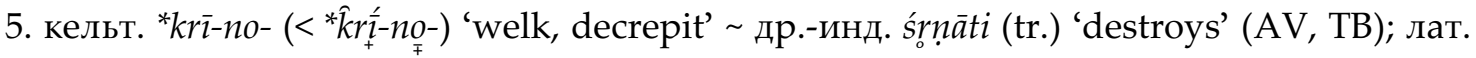
cernit 'sifts, separates, discerns' (<*krineti). ॥ [McCone 1991: 13, 17; Matasović 2009: 224; Дьюис-Педерсен 1954: 414; KEWA III: 371-372; Frisk 1960-1972 I: 822, II: 20-21; IEW: 578 ( $\sqrt{k e r-}$ и kैera- : $\hat{k} r \bar{e}-)]$.

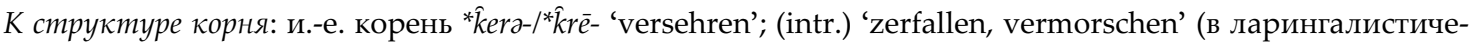

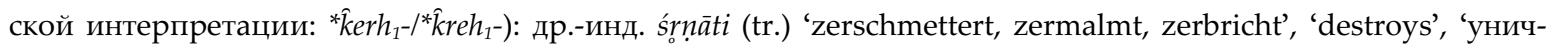
тожает, разрушает', aor. aśarīt (AV, TB); part. śìrná- 'zerbrochen, zersprungen' (AV, Br. u.a.), a-śîrta-(tanu-) 'unversehrt (en Leibes)', śūrtá- 'zerschmettert' (RV); греч. кஹíveı 'separates, determines', 'отделяет, разделяет; опре-

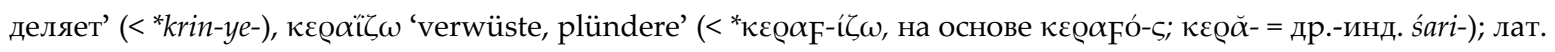
cernit 'sifts, separates, discerns', 'просеивает; отделяет, разделяет; различает' (< *krineti). В данном случае, повидимому, кельтский рефлекс причастия является единственным свидетельством акцентуационной ва- 
лентности (доминантной) корневой морфемы. ॥ [McCone 1991: 13, 17; Matasović 2009: 224; Льюис-Педерсен 1954: 414; KEWA III: 371-372; Frisk 1960-1972 I: 822, II: 20-21; IEW: 578 ( V ker- и k̂kera- : k̂rēe-)].

6. кельт. *mlinno- 'müde' (<*blìno-); лтш. blīnis 'ein müder, matter Mensch, der sich nicht bewegen kann', лтш. blinêt Doblen, Siuxt 'sehen, lauern, glupen, gaffen, faulenzen'; схрв. млийтав 'вялый, апатичный, дряблый; не́мощный, слабый', mlitati 'faul werden' [RJA VI: 814] др.-инд. mláyati 'welkt'; также *mūrṇa- 'schlaff geworden, verwelkt' в ŚB (Kāṇv.) parimūrṇ̄a. || [Barber 1932: 117, 121; Heidermanns 1993: 132-133; Raven 1963-1967 I: 10; IEW: 155-156, 716-718; Feist 1939: 99; Orel 2003: 49; Mayrhofer KEWA II: 698-699; Mayrhofer EWA II: $319-320,387-388,388-389]$.

К структуре корня: см. под В. -to-основы, 7, кельт. mláto-.

Таким образом, для данного типа кельто-италийских производных мы получили следующее распределение материала: Табл. 1.

После того как Фредерик Кортландт познакомил англоязычного читателя с выводами и материалом моей работы [Дыбо 1961] в статье [Kortlandt 1981], изложенные в моей работе данные по сокращению индоевропейских долгот в германских языках в предударном положении перед сонорными были приняты, по-видимому, без возражений. В кельтологии же предложенные материалы и их объяснение вызвали определенную дискуссию, приведшую к ряду результатов фактографического и теоретического характера. С фактографической стороны значительно увеличилось количество материала, требующего и получающего объяснение в рамках предложенной теории.

Исследователи разделились на тех, кто не принимает предложенное мной правило, и тех, кто его принимает (в основном как спорадическое сокращение в предударном положении). Но в ходе дискуссии объем данных увеличивается. Не принимающие правило собирают материал, фактически подтверждающий парадигматический выбор. Так, 30 примеров, приводимых [Isaac 2007], которые, по его мнению, отрицают правило сокращения, на деле достаточно точно соответствуют «второму правилу» (как назвал его В. М. Иллич-Свитыч в статье «О втором правиле Дыбо»). Отбросив мои (и Педерсена!) рефлексы сокращенных ${ }^{*}-\bar{r}-,{ }^{*}-\bar{l}->-a r-,-a l-$, исследователи заменили их на -ră-, -lă-. В этой группе наблюдается ряд любопытных примеров. Из них наиболее интересны:

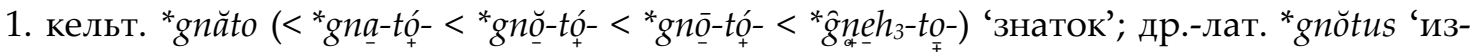
вестный' (< * gonō-tó-): лат. nŏta f. 'Знак, отметка', nŏtāre 'обозначать, отмечать', cognitus 'известный, знакомый', agnitus 'признанный' предполагают др.-лат. *gnŏtus 'известный'; ср.

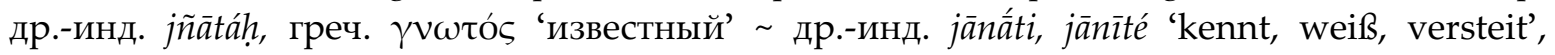
jijñāsate ‘verlangt kennenzulernen, wünscht zu erfahren'. ॥ [Irslinger 2002; Дыбо 1961: 13; WH II: 177-178; IEW: 376-378; LIV ; Isaac 2007: 28].

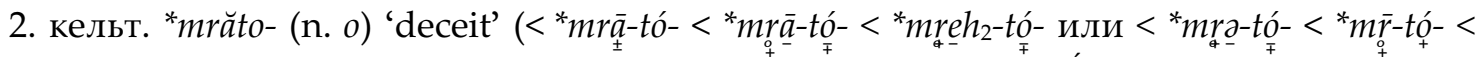

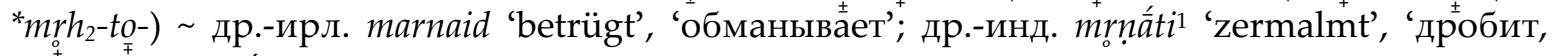

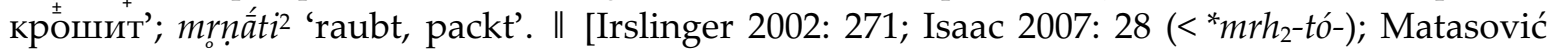
2009: 279-280; KEWA II: 672-673, 673; Frisk 1960-1972 II: 177-178; Skok II: 472; IEW: 735-736; LIV 2 : 440].

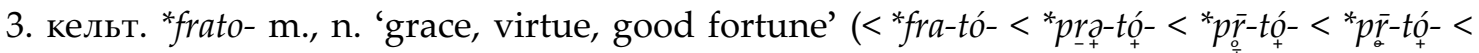
* $p r h_{3}$-tó-) или кельт. *rato- n. 'grace, virtue, good fortune'; отглаг. сущ. к ernaid 'gewährt; ver- 
Таблица 1. Акцентные типы кельто-италийских отглагольных имен на -t- и -n-.

-

\begin{tabular}{|c|c|}
\hline А. Подвижно-окситонированная а. П. & В. Баритонированная а. 1. \\
\hline 1. лат. rŭtum (< $\left.{ }^{*} r \bar{u} t u ́-\right)$ & 1. лат. sūtum (<*siñ \\
\hline 2. лат. lĭtum (<* $\left.{ }^{*} \bar{\imath}_{t u ́}\right)$ & 2. лат. spūtum (<*spiñútu-) \\
\hline 3. лат. fütu- (<*bhūtú- в füturus) & 3. лат. trītum $\left(<{ }^{*}\right.$ trìtu- $)$ \\
\hline 4. лат. cĭtum (<*kītú-) & 4. лат. strātum (<*stríntu-) \\
\hline 5. ирл. gŭth $(<*$ ghhütú-) & 5. лат. $n \bar{a} t \bar{u}-(<*$ gूónt $t \bar{u}-$ в $n \bar{a} t \bar{u} r a)$ \\
\hline 6. ирл. brŭth (<*bhrūtú-) & 6. ирл. bith (<*bhítu- в fo-bíth) \\
\hline 7. ирл. büth (<* gūitú-) & 7. ирл. bráth (< *bhrítu-) \\
\hline
\end{tabular}

-

\begin{tabular}{|c|c|}
\hline А. Подвижно-окситонированная а. I. & В. Баритонированная а. 1. \\
\hline 1. лат. rŭtus (<*rūtó-) & 1. лат. sūtus (<* siñ to-) \\
\hline 2. лат. lïtus (<*lìtó-) & 2. лат. spūtus (<*spińúto-) \\
\hline 3. лат. fŭto- (< *bhūtó- в fütāre) & 3. лат. pūto- (<*púto- в pūtēre) \\
\hline 4. лат. cĭtus (<*kītó-) & 4. лат. rūto- (<*rúto- в rūta) \\
\hline 5. лат. pütus (<*pūtó-) & 5. лат. trītus $(<*$ trí -to-) \\
\hline 6. лат. * gnŏto- (<*ĝnōtó-) & 6. лат. grātus (<* gou $\left.{ }^{u} \frac{\dot{r}}{o} t o-\right)$ \\
\hline 7. лат. pŭto- (< *pūtó- в pŭtāre) & 7. лат. strātus (<*st⿳亠丷厂̆to-) \\
\hline 8. лат. in-clŭtus (<*k̂klūtó-) & 8. лат. stlātus (<*stî́to-) \\
\hline 9. лат. de-frŭtum (<*bhrūtó-) & 9. лат. nātus (<*ôgnt \\
\hline 10. ирл.*both (<*bhūtó- в ro-both) & 10. ирл. bith (<*bhìto- в ro-bith) \\
\hline 11. ирл. cloth n. 'Ruhm'(<*k̂kūtóm) & 11. валл. prid (<*kuríto-) \\
\hline 12. валл. brwd 'heiß' (< ‘bhrūtó-) & 12. кельт. *mlāto- 'flour' (<*mílto-) \\
\hline 13. брет. skant 'Schuppen' $\left(<{ }^{*}(s) k n ̄ t o ́-\right)$ & 13. ирл. gnáth (<*ợnto-) \\
\hline 14. кельт. ${ }^{*}$-balto- $\left(<{ }^{*}-g^{u} \bar{I}-\right.$ tó- $)$ & 14. кельт. ${ }^{*}$-gnî́to- (< *gnéto-) \\
\hline 15. кельт. ${ }^{*} \tan t \bar{a}-\left(<{ }^{*} t \bar{n}-t \bar{a}-\right)$ & 15. кельт. ${ }^{*}$-ríto- (< и.-е. ${ }^{*} h_{2}$ réto- $/{ }^{*} h_{2}$ ríto- $)$ \\
\hline
\end{tabular}

-по-основы

\begin{tabular}{|c|c|}
\hline А. Подвижно-окситонированная а. & В. Баритонированная а. \\
\hline 1. кельт. *darno- 'piece, part' (< *dīnó-) & 1. кельт. *fláno- 'full' (< *pítno-) \\
\hline 2. кельт. *starno- 'pavement' (< *str̄nó-) & 2. кельт. *grāno- 'grain' (< *ôğ \\
\hline 3. кельт. barno- 'Richter', 'Urteil', 'judgement' & 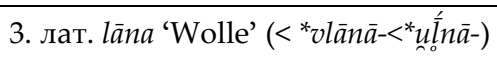 \\
\hline 4. кельт. *drŭna- 'fest' (< *drū-nó-): др.-ирл. dron 'fest' & 4. кельт. *mūno- 'urine' (< *múno-) \\
\hline 5. кельт. *lono- ‘баран (холощеный)’ (< *lūnó-) & 5. валл. blin 'müde' (< ${ }^{*}$ blìno-) \\
\hline
\end{tabular}

leiht', 'предоставляет; дает взаймы, напрокат; награждает'. II [Irslinger 2002: 272; Matasović 2009: 140, 122; IEW: 816 f.; LIV $_{2}$ : 427].

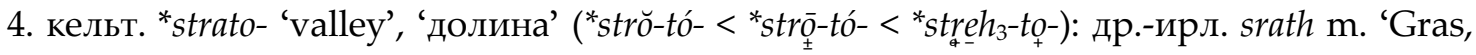
Rasen, Tal, Grund', ‘дно долины'; валл. ystrad 'valley’; прагерм. *strōđú- < *strōpú- (др.-англ. 
strōd n. 'bewachsenes Sumpfland', н.-англ. strood; др.-в.-нем. struot 'болото, болотистое место; кустарник', ср.-в.-нем. struot, strût stf. 'Sumpf; Gewoge, Flut; Gebüsch, Buschwald, Dickicht')

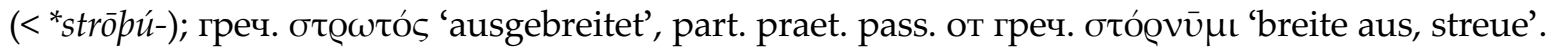
|| [Irslinger 2002: 275; Isaac 2007: 28: (< ${ }^{*}$ strh $_{3}$-tó-); WH II: 590-591; Holthausen 1934: 327; Lexers 1956: 215a].

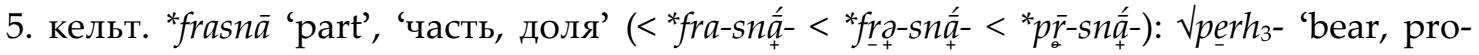
vide'. II [Matasović 2009: 138-139 (<* prh $_{3}$-snéh $2^{-}$'gift, share’); IEW: 817].

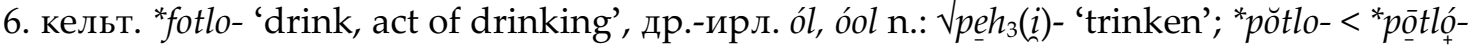
< ${ }^{*}$ ẹh-tló- > *potlo-) || [Matasović 2009: 137-138; LIV 2: 462; IEW: 839-840].

Все три суффикса, представленные в данных производных (субстантивирующий $\left.-t_{+}{ }^{2},-s n \bar{a}-,-t l o-\right),-$ доминантные, все корни рецессивны или могут быть таковыми.

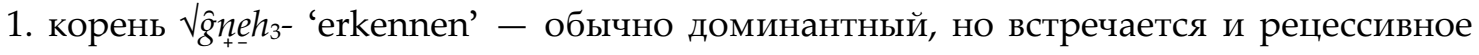
употребление (что, согласно принимаемой мною тонологической интерпретации, свидетельствует о нисходящем тоне);

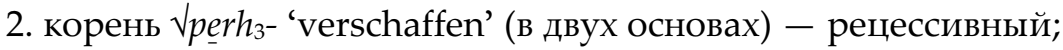

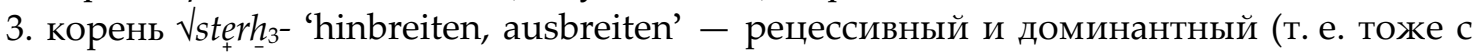
нисходящим тоном);

4. корень $\sqrt{p e h}_{3}(\mathrm{i})$ - 'trinken' - рецессивный;

5. корень $\sqrt{m e r h}_{2^{-}}$'gewaltsam packen, zerdrücken' - для установления акцентуационной валентности нет материала.

В основах с акутированными рецессивными корнями при доминантных суффиксах в балтославянском происходила метатония (корни становились доминантными, «рецессивный» акут заменялся «доминантным» циркумфлексом). Ударение при этом падало на вторично доминантный корневой слог. До метатонии ударение, конечно, при рецессивном корне стояло на доминантном суффиксе. Но вся проблема в том, когда произошла эта метатония. В ведийском в словах с рецессивными корнями и с доминантным суффиксом -tlo- ударение стоит на корне. Это значит, что метатония в индоевропейском произошла раньше, чем из него выделился индоиранский. Следовательно, в кельтском ударение в этих основах могло стоять на суффиксе лишь в том случае, если он выделился из индоевропейского значительно раньше индоиранского и, по-видимому, раньше всей греко-арийской группы. Нисходящий тон перешел в низкий перед высоким слогом, вероятно, еще раньше. Так как тоновый характер доминантного суффикса - высокий должен отличаться от характера суффикса, получившего свою доминантность из-за стяжения с ним доминантных окончаний - восходящего, - то позиции двух типов рефлексов рецессивных долгих слоговых плавных и носовых (-ar-, -al-, -an-, -am- и -ră-, -lă-, -nӑ-, -тӑ) будут разными, и мы можем обойтись без предположения о метатонии в соответствующем слоге. Имеется, однако, один момент, делающий гипотезу метатонии весьма заманчивой: это поствокалический рефлекс слоговых сонантов и носовых в ударном слоге и предвокалический в предударном (см. ниже). Если мы примем, что метатония в подобных основах уже произошла, то можно думать, что резко восходящий акцент на метатонированном корневом слоге вызвал метатезу сочетаний -ar-, -an- > -ră-, -năи сокращение $-\bar{o}->-\breve{o}$ -

2 Суффикс отглагольных прилагательных *-to- рецессивный, и подвижность их акцентной парадигмы и, соответственно, окситонеза в греко-арийском, кельто-италийском(?) и германском(?) возникла из-за доминантных окончаний. 
Таким образом, предложенную Р. Матасовичем рефлексацию *-ră-, *-lă-, *-nă-, *-тӑ- в виде долгих слоговых плавных и носовых в пракельтском в предударной позиции следует, скорее всего, считать не сокращением первичных рефлексов доминантных долгих плавных и носовых $\left({ }^{*}-r \bar{a}-,{ }^{*}-l \bar{a}-,{ }^{*}-n \bar{a}-,{ }^{*}-m \bar{a}-\right)$, а метатезой первичных рефлексов рецессивных долгих плавных и носовых (*ar-, *-al-, *-an-, *-am-) в позиции перед доминантным суффиксом. Такое решение позволяет легко объяснить и часто появляющуюся рефлексацию *-ră-, *-lă-, *-nă- вместо или наряду с рефлексацией ${ }^{*}$-ar-, ${ }^{*}$-al-, ${ }^{*}$-an- в формах to-part. и пассивного претерита: доминантность, первоначально свойственная лишь определенным окончаниям, при стяжении с суффиксальным слогом передается суффиксу, что затем распространяется на всю основу.

Теперь следует рассмотреть рефлексацию двух акцентных парадигм личных форм пракельтского глагола. Так как этим парадигмам соответствуют две парадигмы балтославянского, которым в корпусе «долготных» глагольных корней соответствуют славянские а. п. $а$ и а. п. с, обозначим таким же образом и пракельтские акцентные парадигмы. Ниже под арабской цифрой приводятся реконструкция пракельтской презентной основы и соответствующие материалы кельтских языков. Для подтверждения первичного акцентного типа и проверки сохранения парадигматического выбора акцентных типов глагольных категорий и отглагольного словообразования ниже под той же цифрой с добавлением соответствующей буквы латинского алфавита приводятся именные формы глагола и определенные отглагольные именные производные.

\section{А. Гдагоды с баритонированной акцентной парадигмой (а. п. $a$ ).}

1) Рефдексы додгих монофтонгов в а. п. $a$.

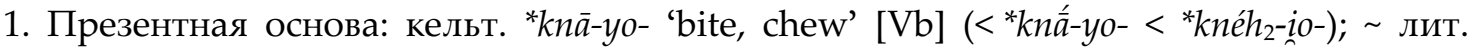
knóti, praes. $1 \mathrm{sg}$. knóju, praet. 1 sg. knójau 'zdzierać (korę), odłupywać'; греч. кvó $\omega$ 'skrobać;

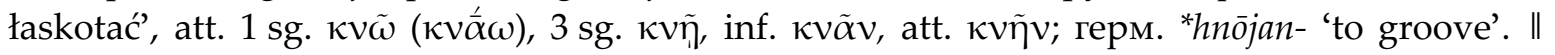
[Matasović 2009: 211; Smoczyński 2007: 303; Frisk 1960-1972 I: 880-881; Kroonen 2013: 237; Orel 2003: 181].

К структуре корня: и.-е. корень *kenд- *nā- (в ларингалистической интерпретации: ${ }^{*} k e n h_{2^{-}} \sim{ }^{*} k n e h_{2^{-}}$)

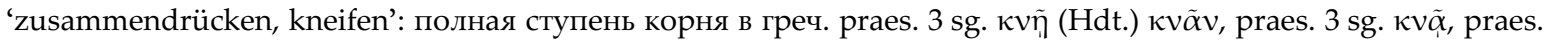
1 sg. күฑ่ $\vartheta \omega$ 'schabe, kratze; jucke’; др.-в.-нем. пиоеn 'durch Schaben glätten, genau zusammenfügen'; лит. knóti, praes. 1 sg. knóju 'драть, обдирать, лупить', knótis, praes. 1 sg. knójuos 'отставать, отдираться, отлупляться’, диал. жемайт. knióties, praes. 3 sg. kniójas 'atšokti, kerti, knotis' [Vitkauskas 1976: 145]. Доминантность корня показывают германские данные. II [Orel 2003: 180; Frisk 1960-1972 I: 880-881, 887; IEW: 562 (558-563)].

2. Презентная основа: кельт. * $r \bar{a}-y 0-$ 'row' (< ${ }^{*} \frac{\dot{c}}{r}-j o-$, как лтш., или < * $r \bar{o}-j o-$ как герм.);

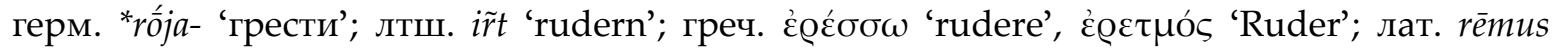
'Ruder'; др.-ирл. rāme 'Ruder'. II [Matasović 2009: 306; Льюис-Педерсен 1934: 447; Orel 2003: 306; Mühl.-Endz. I: 710; KEWA I: 49].

К структуре корня: и.-е. корень *eré-/* ${ }^{*}$ - (в ларингалистической интерпретации: ${ }^{*} h_{1} e r e h_{1}-{ }^{*} h_{1} r h_{1}-$ ): полная

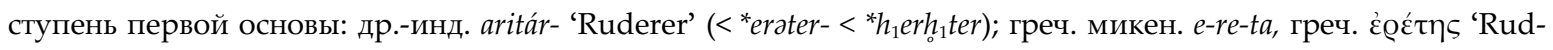
erer'; полная огласовка второй основы: лат. rēmus 'Ruder'; -о-огласовка второй основы (?) или кельтский

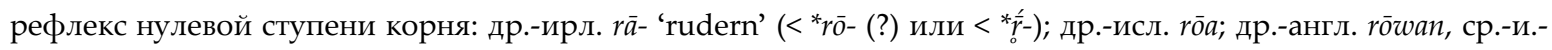
нем. rüejen 'rudern'; др.-исл. rōpr 'das Rudern'; др.-англ. rōđor, др.-в.-нем. ruodar n. 'Ruder'; нулевая огласовка корня: лит. ìtti 'rudern', praes. 1 sg. iriù; лит. irklas 'Ruder'; лтш. iřkls 'Ruder'. Доминантность корня показы- 
вают балтийские и германские данные. ॥ [Seebold 1970: 381-382; Fraenkel 1962-1965: 187; Trautmann 1923:

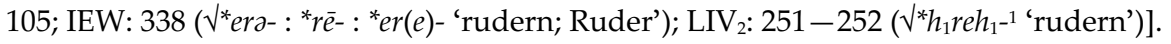

2а. Отглагольное имя на -tro-: др.-инд. áritram, arítram n. 'Steuerruder’; arítrah m. 'Ruder' герм. *rốpraz *rṓpran m./n. (др.-исл. rōpr 'Ruder'; др.-англ. róðеr; др.-фриз. rōder; ср.-н.-нем. rōder; др.-в.-нем. ruodar). ॥ [Orel 2003: 307].

3. Презентная основа: кельт. *gnín-o- 'beget, create, do' [Vb] (< *gné́y-o/e-), формы презенса сохраняют баритонезу, парадигматический выбор акцентных типов подтверждается кельт. *-gníto-; др.-инд. jánati 'erzeugt, gebiert', jánima, jánma (-an-) n. 'Geburt, Ursprung'. II [Thurneysen 1980: 438; Matasović 2009: 163-164; KEWA I: 415, 416; IEW: 373-374].

К структуре корня: см. под В. -to-основы, 4, кельт. *-gníto-.

За. Отглагольное имя (adj.) на -to-: кельт. *-gnîto- 'порожденный, сотворенный’ (<*-gnếto-) part. praet. pass. conjunct. от др.-ирл. praes. 1 sg. gnīu 'ich mache, tue’. ॥ см. под В. -to-основы, 4.

\section{2) Рефлексы кратких и долгих монофтонгов в а. п. $a$.}

4. Презентная основа: кельт. *be-na- < *bi-na- 'strike, hit' [Vb], краткость корневого гласного объясняется вставкой -ne-/-n-инфикса между $i-$ и ларингалом; слав. pras. $1 \mathrm{sg}$. *bîjo, 3 sg. *bîjetb; sup. *bîtb; l-part. *bílt, f. *bíla.\| [Matasović 2009: 65-66; McCone 1991: 11; Дыбо 1961: 15, 19, 31-32; Pedersen 1908-1913 II: 461 ff., WH I: 502-504; IEW: 117-118 $(\sqrt{ } b h e i(a)-/ b h \bar{l}-)]$.

К структуре корня: см. под В. --о-основы, 1, кельт. *bíto-.

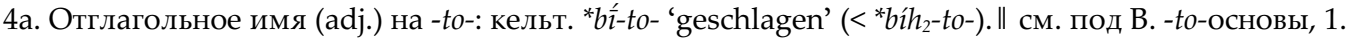

5. Презентная основа: кельт. * $k^{w} r i-n a-~ ' b u y ' ~[\mathrm{Vb}]\left(<{ }^{*} k^{w} r i-n e-h_{2^{-}}\right)$, краткость корневого гласного объясняется вставкой -ne-/-n-инфикса между $i$ - и ларингалом; др.-инд. krīnáti, с восстановлением долготы *-і- по неличным формам глагола; ср. др.-русск. крьнути 'купить', praes. 3 sg. крьнеть, где рефлекс говорит о сохранении первичной краткости; баритонеза подтверждается и славянским материалом: др.-pyсcк. part. praet. pass. укриенъ 'купленный', ср. ст.-слав. оүкрнєнъ 'куплен', последний свидетельствует о баритонезе восстанавливаемой праславянской формы *krítos (в ст.-слав. языке баритонированные причастия на -tos были заменены причастиями на -enos); о существовании ранее в славянском причастия на -tos от этого глагола свидетельствует производное от этого причастия существительное: по|критии 'по искуплении' [Усп. сб. 207в14-15]. ॥ [Matasović 2009: 182; Аьюис-Педерсен 1934: 335; Isaac 2007: 27-28 (< $\left.\left.{ }^{*}{ }^{w} r i h_{2}-t o ́-\right)\right]$.

К структуре корня: см. под В. -to-основы, 6, кельт. * $k^{w} r \bar{i}-t o-$.

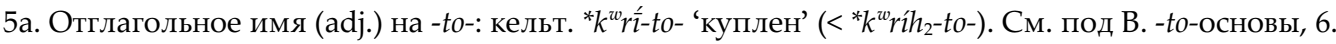

bb. Отглагольное имя (sup.) на -tu-: кельт. ${ }^{*} k^{w} r \bar{t}-t u-\left(<{ }^{*} k^{w} r i h_{2}-t u-\right)$. См. под В. -tu-основы, 4.

6. Презентная основа: кельт. *re-na- < *ri-na- 'count, sell, exchange', др.-ирл. renaid 'sells', 'продает' (< кельт. * $\left.r i-n a-<{ }^{*} h_{2} r-n \bar{a}-<{ }^{*} h_{2} r-n e h_{1}-\right)$, краткостный рефлекс корневого $-r$ объясняется вставкой -ne-/-n-инфикса между -r- и ларингалом; долготный рефлекс сохраняется в кельт. * to-): др.-ирл. -ríth praet. pass. conjunct. от renaid 'sells', 'продает'; ср. кельт. *rīmā 'number, count' (Noum) [др.-ирл. rím [ā f.]; ср.-валл. rif [m.]; ср.-брет. ri(m) gl. summa]. ॥| [McCone 1991: 37-40; Irslinger 2002: 27-28; Matasović 2009: 313].

К структуре корня: см. под В. -to-основы, 15. кельт. * ${ }^{*} r \bar{e}-t o-$ или *-rí-to-.

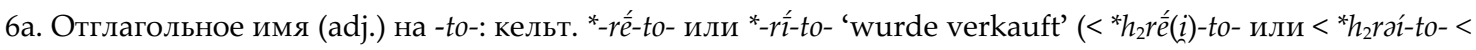
${ }^{*} h_{2} r h_{1} i$-to-), см. под В. -to-основы, 15. 


\section{3) Рефлексы кратких и додгих слоговых сонантов в а. п. $a$.}

7. Презентная основа: кельт. *gni-na- 'recognize' [Vb] (<* $\left.{ }^{*} g_{o}-n e h_{3^{-}}\right)$, краткостный рефлекс -n- объясняется вставкой -ne-/-n-инфикса между -n- и ларингалом; долготный рефлекс -⿳亠丷厂二- $\left(<-n H_{-}\right)$или долгота второй основы сохраняется в кельт. *gnáto- 'known, usual'

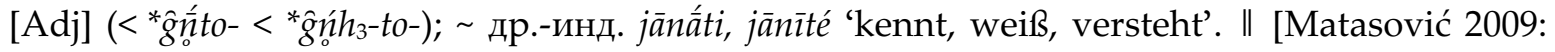
162; KEWA I: 446, 446-447; Fraenkel 1962-1965: 1300-1301; IEW: 377; Дыбо 1961].

К структуре корня: см. под В. -to-основы, 3, кельт. *gnáto-.

7а. Отглагольное имя (adj.) на -to-: кельт. *gnáto- 'known, usual' (< *ağñto- < *ågńh *ânóh ${ }_{3}$-to-). II [Matasović 2009: 162; Isaac 2007: 27 (<*ónohoh

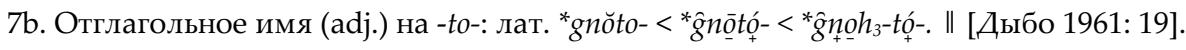

7с. Отглагольное имя на -tro-: др.-инд. jñátram n. 'Erkenntnisfähigkeit, Einsicht' прагерм. *knốpla- [в

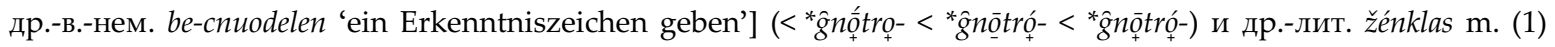

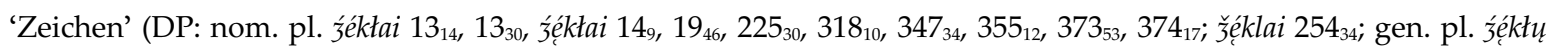

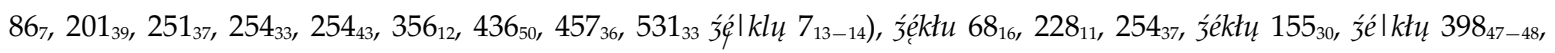

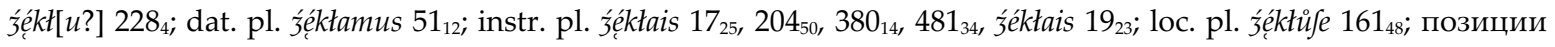
закона Соссюра: instr. sg. ร̌ék $t u$ 51 $, 51_{14}, 51_{20}, 51_{32}, 54_{9}, 54_{12}, 54_{21}, 69_{33}, 119_{50}, 152_{37}, 174_{4}, 294_{46}, 455_{23}, 455_{43}, 455_{48}, 456_{3}$,

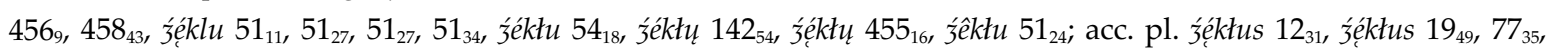

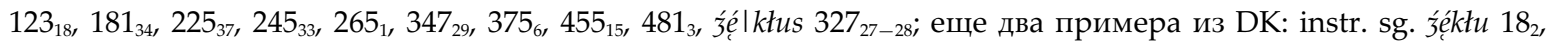

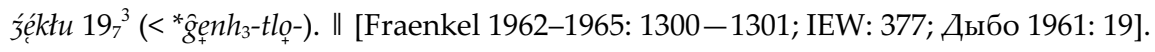

8. Презентная основа: кельт. *kri-ni- 'sift, shake' [Vb]: ([IEW] < *-k̂kr-nu-t); др.-инд. śrnāti tr. 'zerschmettert, zermalmt, zerbricht' (AV, TB); part. śìrná- 'zerbrochen, zersprungen' (AV, Br. u. a.), a-śìrta-(tanu-) 'unversehrt(en Leibes)', śūrtá- 'zerschmettert' (RV); лат. cernit 'sifts, separates, discerns' (<*krineti). II [McCone 1991: 13, 17; Matasović 2009: 224; Аьюис-Педерсен 1934: 414; KEWA III: 371-372; Frisk 1960-1972 I: 822, II: 20-21; IEW: 578].

К структуре корня: см. под В. -по-основы, 5, кельт. *krí-no-.

8а. Отглагольное имя на -no-: кельт. *krí-no- 'welk, decrepit': др.-ирл. crín (W. crin) 'welk', 'decrepit' ([Аьюис-Педерсен 1934] 'увядший', приводится также ирл. crínaim 'вяну'; валл. сrino 'вянуть'); см. под В. -поосновы, 5 .

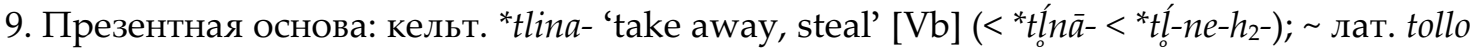
$\left(<{ }^{*} \ln \bar{o}\right.$, перестройка древнего $\left.{ }^{*} \operatorname{tln} \bar{a} m i\right)$ 'hebe auf, hebe weg, entferne'. На доминантность корневой морфемы может указывать слав. *tolíti, praes. 1 sg. *toljö, 3 sg. *tòlīts - а. п. b. \| [Matasović 2009: 380; WH II: 688-689; IEW: 1060-1061].

К структуре корня: см. под В. -to-основы, 16. лат. part. praet. pass. lātus.

9а. Отглагольное имя на -to-: лат. part. praet. pass. lātus (< *tātos < *ț́l-to-) ‘getragen'. ॥l [Matasović 2009: 380; IEW: 1060-1061; WH I: 772; II: 688-689], см. под В. -to-основы, 16.

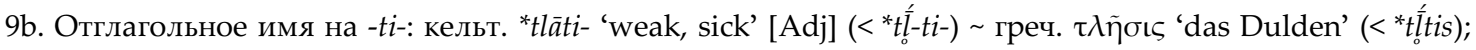
герм. * púlpi и *bulđi. II [Matasović 2009: 380; Orel 2003: 428; Barber 1932: 31; Feist 1939: 504-505; Frisk 1960-1972 II: 848-849; WH I: 772; II: 688-689; IEW: 1060-1061].

10. Презентная основа: кельт. *kli-nu- 'hear' [Vb] (<* *kíl-n-u-; предложено объяснение этой формы как результата транспозиции формы *klu-ni-, извлеченной из приставочных

\footnotetext{
${ }^{3}$ Кроме этих примеров и примеров, нерелевантных по отношению к грамматической подвижности и

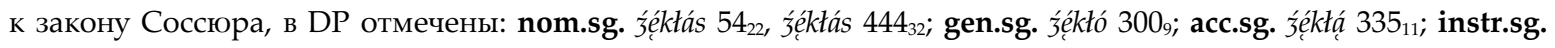

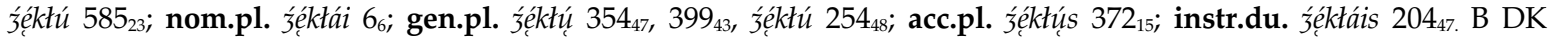
отмечен nom.sg. ร̌e kłás DK 1515. Эти данные явно не влияют на определение а. п. этого слова.
} 
типа др.-ирл. ro-cluinethar [< ${ }^{*}$ fro-kli-nu-tor], но это предложение лишь ставит под сомнение точность пракельтской реконструкции, не отвергая само сближение); эта этимоло-

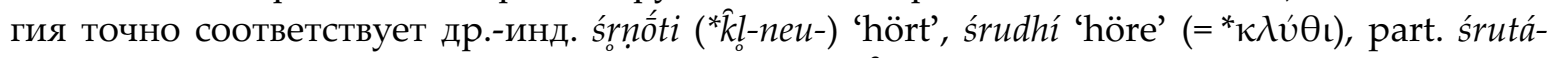

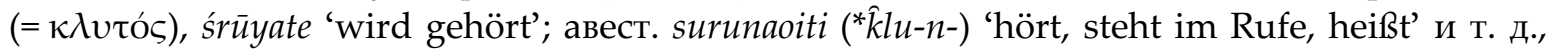
part. srūta- 'gehört, berühmt', srŭti 'das zu Gehörbringen, Vortrag', др.-инд. śraváyati 'läßt hö-

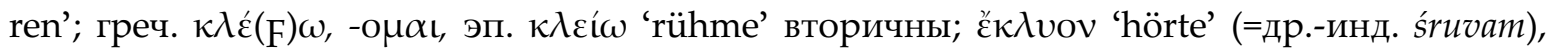

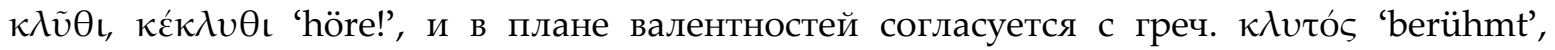

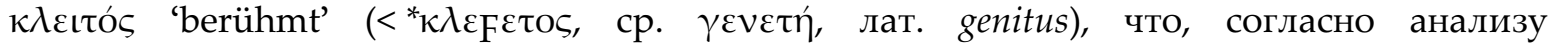
С. Л. Николаева $(1983 ; 1986)$, данный корень мог относиться к I классу, т. е. быть доминантным; однако показания балтославянского и германского [др.-в.-нем. $h l \bar{u} t$, др.-англ. $h l \bar{u} d$, др.-сакс. $h l \bar{u} d$, н.-в.-нем. laut] относят его к рецессивным. ॥ [McCone 1991: 13; Matasović 2009: 208].

К структуре корня: см. под А. -to-основы, 15. кельт. ${ }^{*}$-kluto-.

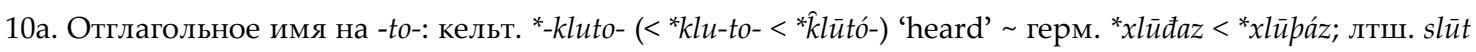

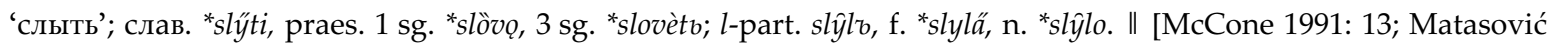
2009: 208; Дыбо 2000: 286], см. под А. -to-основы.

\section{В. Гдагоды с окситонированной (подвижной) акцентной парадигмой (а. п. c). 1) Сокращение долгого монофтонга в а. п. $c$.} -іе-гдаголы:

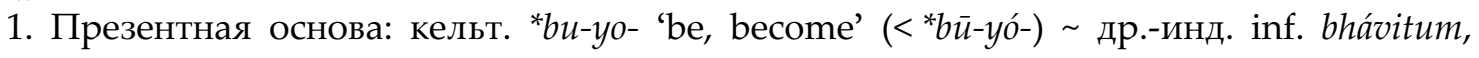

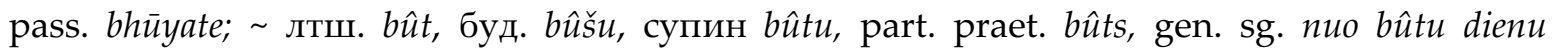
[Endz.Gr. 798]; слав. *býti, l-part. bŷltb, f. *bylä, n. *bŷlo. ॥ [McCone 1991: 37; Irslinger 2002: 400-409; Matasović 2009: 85].

К структуре корня: см. под А. -tо-основы, 2. кельт. *buto-.

1а. Отглагольное имя на -to-: кельт. “buto- (<*bhū-tó-), part. praet. pass. от кельт. ‘bu-yo- 'be, become’. ॥ [McCone 1991: 37; Irslinger 2002: 400-409; Matasović 2009: 85], см. под А. -to-основы, 2.

2. Презентная основа: кельт. *dam-yo- 'allow, permit, endure' [Vb] $\left(<* d \bar{m}-i o^{*}-<{ }^{*} d m h-i o^{\circ}\right)$;

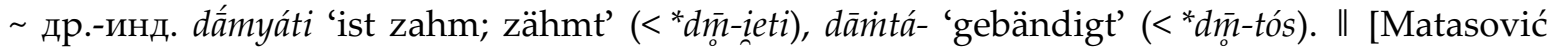
2009: 88; IEW: 199-200].

К структуре корня: и.-е. корень *demə-/*dmā-/*dīn- 'zähmen, bändigen' (в ларингалистической интерпретации: ${ }^{*} d e m h_{2}{ }^{*}{ }^{*} d m e h_{2}{ }^{\prime *} d m h_{2}$ ): др.-инд. dámyati 'ist zahm; zähmt' (см. [KEWA II: 35]: < *dīn-ieti), dāmitá- 'gebändigt' (< ‘dī-tós); корень в греческом языке относился ко II классу (т. е. был рецессивным), что было показано С. А. Николаевым в работе «К исторической морфонологии древнегреческогоглагола» [Николаев 1983, 1986]. ॥ [KEWA II: 35 (dấmyati Br.); EWA I: 698 (imp. dâmyata 'seid ruhig, seid zahm!' ŚB); IEW: 199-200 (dāmyáti); ОСА (Словарь): 181; Николаев 1983: 80; Николаев 1986: 185-187].

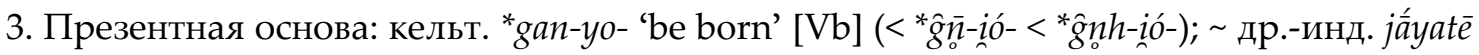
'wird geboren'; авест. zayeite ‘wird geboren', н.-перс. zāyad 'wird geboren'. I| [Matasović 2009:

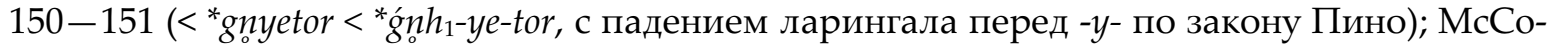
ne 1994: 70; IEW: 373-374; $\operatorname{LIV}_{2}$ : 163-165].

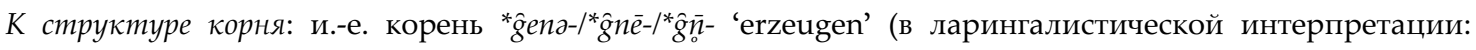

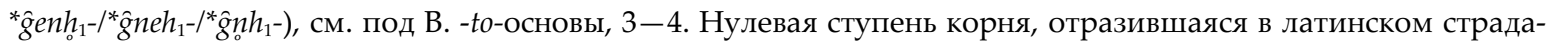
тельном причастии прошедшего времени, хорошо представлена в германском: герм. *kúnpa-z part. 'рожденный' [др.-исл. -kunnr в др.-исл. alf-kunnr adj. 'af alve-herkomst', ás-kunnr adj. 'oprunden af aserne, af gudeherkomst; богорожденный', regin-kunnr adj. 'fra guderne stammende, om runerne'; др.-в.-нем. aD gomman-kund 'männlich', MF man-kund 'männlich', T, BR, aD, Ab got-kund 'göttlich'; в гот. ga-kunps 'Geburt' (только в uf 


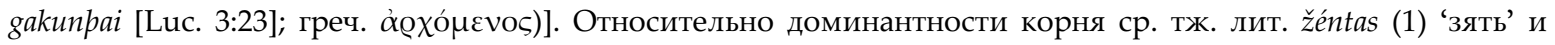

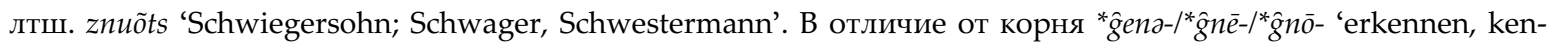
nen', этот корень показывает доминантность во всех формах (ступенях аблаута). Следовательно, в индоев-

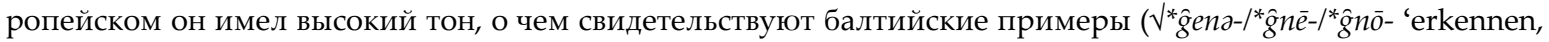
kennen', как показано выше, имел, вероятно, нисходящий тон). Так что поведение данного корня в представленном пассиве легче всего объяснить просодической контаминацией с $\sqrt{ }^{*} g \mathrm{~g} \mathrm{~h}_{1}$ - $^{*} \mathrm{~g}_{\mathrm{g}} h_{1^{-}}$' 'erkennen, kennen', - надежнее, чем принимать закон Пино, так как ряд кельтских материалов, приведенных выше, этот закон не поддерживают. ॥| [WH I: 597-600; Дыбо 1961: 9-34; Дыбо 2007; IEW: 373-375].

\section{-nе-гдагоды:}

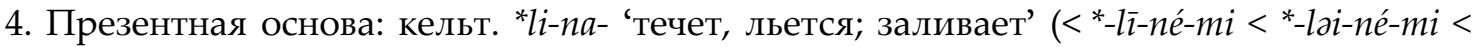
*-lhó $i$-né-mi или < *-lē-né-mi < *-leh $-n e ́-m i)$. || [Matasović 2009: 239; Преображенский: 458459; Дыбо 1961: 22; Дыбо 2000: 283, 330, 489, 495, 508, 533 (Vlēi-/lai-); Фacmep II: 504; Fraenkel 1962-1965: 368; Mühl.-Endz. II: 491, 505; WH I: 794-795; IEW: 664-665 (V*lĕi-); cp. McCone 1991:

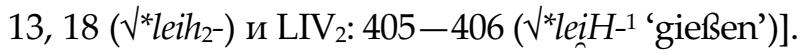

К структуре корня: и.-е. корень *lēi-/*li- (в ларингалистической интерпретации: *leh $\left.h_{1}-{ }^{*} l h_{1} i-\right):$ лит. líeti, praes. $1 \mathrm{sg}$. líeju 'лить', lýti, praes. $3 \mathrm{sg}$. lĩja 'идти (о дожде); лтш. lît, praes. $1 \mathrm{sg}$. lîstu 'изливаться, струиться’,

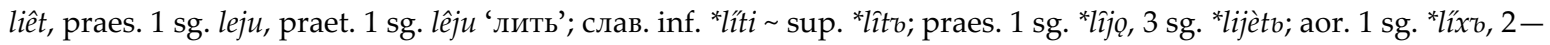
3 sg. *lîtı; l-part. *lilı, f. *lilä, n. *lîlo, part. praet. act. *livø, f. *livъší, part. praet. pass. *litı, f. *litä, n. *lito; inf. *lojäti sup. *löjatr; praes. $1 \mathrm{sg}$. *lějo, $3 \mathrm{sg}$. *lějètb; aor. $1 \mathrm{sg}$. *lojäxb, 2-3 sg. *löja или *lïjatb; l-part. *lb̈jalb, f. *lbjalä, n. *löjalo; part. praet. act. *löjavъ, f. *lbjavъší; part. praet. pass. *löjanъ, f. *lbjanà, n. *lb̈jano. ॥ [Matasović 2009; Дыбо 1961: 22; Дыбо 2000: 283, 330, 489, 495, 508, 533; Фасмер II: 504; Fraenkel 1962-1965: 368; Mühl.-Endz. II: 491, 505;

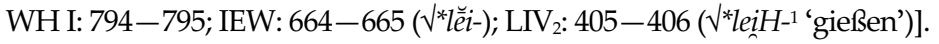

5. Презентная основа: кельт. ${ }^{*} d e-n a-\left(<* d \breve{\imath}-n a-\right.$ или $\left.{ }^{*} d \breve{e}-n a-\right)$ 'suck' [Vb] $\left(<{ }^{*} d h \bar{\imath}-n e-m i ́<\right.$

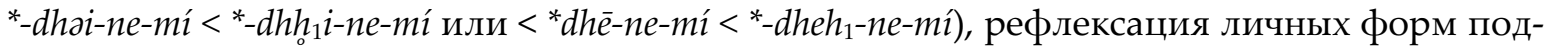
тверждает их окситонезу; др.-инд. dháyati 'saugt, trinkt' (< *dháieti), dháyas- n. 'das Saugen'; лтш. dêt, praes. 1 sg. dêju 'saugen'; слав. caus. inf. *dojîti супин *döjitъ; praes. 1 sg. *döjo, 3 sg. *dojítı; l-part. f. *dojilä. ॥| [Matasović 2009: 99; Дьюис-Педерсен 1934: 417; Дыбо 1961: 22; Дыбо 2000: 575, 641; Mühl.-Endz. I: 465; KEWA II: 93; IEW: 241 -242].

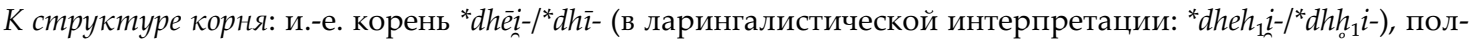
ная ступень этого корня отражена в лтш. dêt, dêju 'сосать' и др.-инд. dhátaven 'zu trinken', (payo)-dhá́- '(Milch)

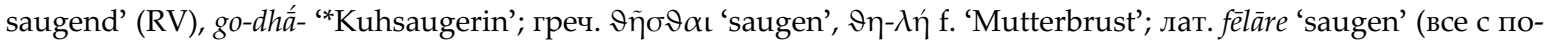
терей второго элемента долгого дифтонга); нулевая ступень: др.-инд. dhītá- 'gesogen’ (AV+); в гетеросиллабической позиции: др.-инд. dháyati 'saugt' < *dhoie-, - a- - регулярный рефлекс -д- перед -i- (др.-швед. dīa 'saugen', датск. die 'saugen', vi. 'сосать (о ребенке), vt. 'кормить грудью’; ср.-в.-нем. dien (tien) 'saugen, die Brust geben' < *dhaie-); фонетически закономерное отражение o-ступени, по-видимому, лишь в герм. *dajja- ‘кормить грудью' (гот. daddjan 'säugen', др.-швед. dæggia 'säugen') < *dhŏii-èie- < *dhōi-èie-. ॥ [KEWA II: 93, 97-98, 101, 113-114; EWA I: 776-777; Frisk 1960-1972 I: 670-671, 673-674, 676-677, 701; WH II: 374-377; Holthausen 1934: 71, 73; Fraenkel 1962-1965: 87; Mühl.-Endz. I: 154; IEW: $241-242$ (ฟ*dhē(i)- ‘saugen, säugen'); LIV 2 : 138$139\left(\sqrt{*} d^{h} e h_{1}(i)-\right.$ '(Muttermilch) saugen')].

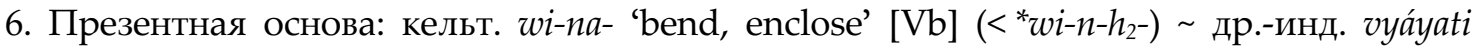
'wraps, envelops', váyati 'webt'; лат. praes. $1 \mathrm{sg}$. vīeō 'binde, flechte', 3 sg. vīet 'bindet, flechtet', лит. výti 'вить'; лтш. vît 'winden; flechten'; слав. inf. *víti sup. *vîtb, praes. $1 \mathrm{sg} .{ }^{*}$ vijo, $3 \mathrm{sg}$. *vijètı; l-part. *vîlı, f. *vilä, n. *villo. II [Matasović 2009: 422; McCone 1991: 11; Fraenkel 1962-1965: 1267; Mühl.-Endz. IV: 645; Фасмер I: 322; Дыбо 2000: 283, 330, 489, 495, 508, 515,523 (Дыбо 1981: 221); KEWA III: 147; WH II: 786-787]. 
К структуре корня: см. под А. -tи-основы, 9. лат. vitus 'Radfelge'.

6а. Отглагольное имя на -tu- и на -to-: лат. vitus 'Radfelge' др.-инд. vittás 'запутанный, витой' лит. výtas, лтш. vîts 'gewunden' слав. part. *vîtъ, f. *vitä, n. *vîto. ॥[ [Дыбо 2000: 283, 330, 489, 495, 508, 515, 523 (Дыбо 1981: 221); Зализняк 2011, II: 135], см. под А. -tu-основы, 9.

\section{2) Метатеза рефлекса долгого сонанта в а. п. $c$.}

7. Презентная основа: кельт. *bal-ni- 'throw away, die' [Vb] $\left(<{ }^{*}-g^{w} a l-n e ́-m i<{ }^{*}-g^{w}{ }_{o}-n e ́-h\right)$, сокращенная рефлексация *-̄- объясняется окситонезой личных форм кельтского глагола, что подтверждается др.-ирл. praet. pass. at-ru-balt 'mortuus est' (<*-gw же рефлексацию в лат. vallessit 'perierit' ( $\left.{ }^{*} g^{w}{ }_{0}^{w}-n i^{-}\right)$; лит. gilti, gélti; лтш. dzêlt 'stechen, brennen, beissen'; герм. *kwelan- [str. vb.] 'to be subject to torture, to die'. ॥ [Matasović 2009: 53; Дыбо 1961: 22; Дыбо 2007: 22; WH II: 729-730; Mühl.-Endz. I: 541; Fraenkel 1962-1965: 145146; Orel 2003: 227; IEW: 470-471; LIV 2 : 207-208].

К структуре корня: см. под А. -tu-основы, 10. кельт. *-balto-.

7а. Отглагольное имя на -to-: кельт. *-balto- [part. praet. pass.]: др.-ирл. praet. pass. atrubalt 'mortuus est' < *-g"Ī-tó-) от глагола др.-ирл. at-baill 'stirbt', 'dies'; лит. gilti, gélti; лтш. dzêlt 'stechen, brennen, beissen'; герм. *kwelan- [str. vb.] 'to be subject to torture, to die'. См. под А. -tu-основы, 10.

8. Презентная основа: кельт. *bar-na- 'proclaim' [Vb] (ср.-брет. barn); др.-инд. grnáti, grnīté 'singt, lobt, preist, kündigt an'. II [Matasović 2009: 57-58; McCone 1991: 19; IEW: 478].

К структуре корня: см. под В. -to-основы, 5. лат. grātus.

9. Презентная основа: кельт. *dam-na- 'subdue, break a horse' [Vb]; греч. $\delta \alpha ́ \mu v \bar{\alpha} \mu \mathrm{l}$,

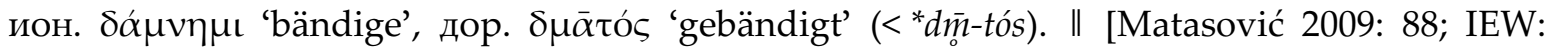
199-200].

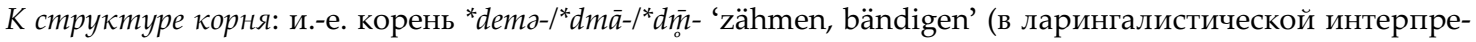

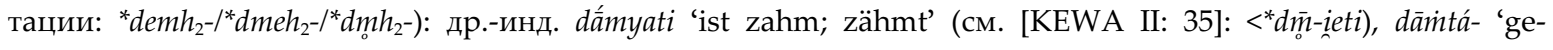
bändigt' (<*dīn-tós); корень в греческом языке относился ко II классу (т. е. был рецессивным), что было показано С. Л. Николаевым в работе «К исторической морфонологии древнегреческого глагола». || [KEWA II: 35 (dấmyati Br.); EWA I: 698 (imp. dấmyata ‘seid ruhig, seid zahm!' ŚB); IEW: 199-200 (dāmyáti); ОСА (Словарь) 181; Николаев 1983: 80; Николаев 1986: 185-187].

10. (?) Презентная основа: кельт. *darna- 'tear up'; личные основы, вероятно, полностью перестроены по именным производным); др.-инд. drnáti 'лопается, трескается, раскалывается’. ॥ Реконструкция основана на неясной валлийской форме [Falileyev 2000: 40; IEW: 206-208; но ср. Stokes 1860: 191, который читет ее как именную; $\mathrm{LIV}_{2}$ : 119].

К структуре корня: см. под А. -по-основы, 1. кельт. *darno-.

10а. Отглагольное имя на -no-: кельт. *darno- 'piece, part' [Noun]: ср.-валл. darn [m]; ср.-брет. darn; корн.

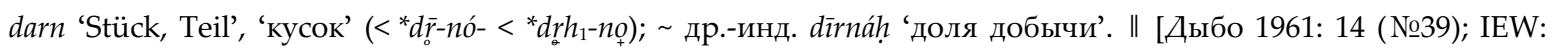
206-208; ср. Matasović 2009: 90]; см. под А. -по-основы, 1.

11. Презентная основа: кельт. *mar-na- 'betray' [Vb] (< ${ }^{*} m \bar{r}-n e ́-h_{2^{-}}<{ }^{*} m r-n e ́-h_{2}-m i$, с восстановлением долготы корневого слога по именным основам); др.-инд. mrṇáti ' 'zermalmt';

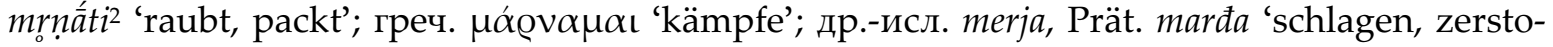
ßen’. ॥ [Дыбо 1961: 22; Matasović 2009: 257; 279-280; KEWA II: 672-673, 673; Frisk 19601972 II: 177-178; IEW: 735-736; LIV 2 440].

К структуре корня: и.-е. корень *теrд- 'aufreiben, reiben; gewaltsam packen, zerdrücken; rauben' (в ларин-

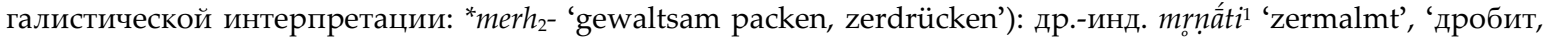




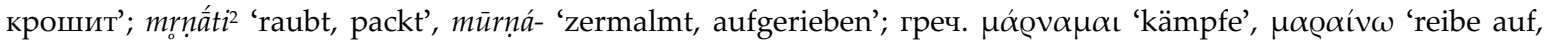
vernichte'; кельт. *mrăto- (n. o) 'deceit’, ‘обман; измена, предательство’: [др.-ирл. mrath [o n.], ср.-ирл. brath; ср.валл. brad [m. and f.] 'treachery, trick'; др.-брет. brat слав. *mъ̌rvā- f. 'крошка' (схрв. mїva f. 'kleiner Brocken'; mìviti, -īm impf. 'drobiti'). || [Irslinger 2002: 271; Isaac 2007: 28 (< $m r h_{2}$-tó-); Matasović 2009: 279-280; KEWA II: 672-673, 673; Frisk 1960-1972 II: 177-178; Skok II: 472; IEW: 735-736; LIV 2 : 440].

11a. Отглагольное имя на -to-: кельт. *-mrath (part. praet. pass. в praet. pass. от др.-ирл. таrnim 'обманы-

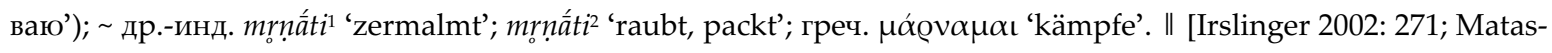
ović 2009: 257; 279-280; KEWA II: 672-673, 673; Frisk 1960-1972 II: 177-178; Skok II: 472; IEW: 735-736; LIV 440; Isaаc 2007: 28 (ошибочно < * $m r h_{2}$-tó-).

11b. Отглагольное имя на -to-: кельт. * mrath 'deceit' [o n].

12. Презентная основа: кельт. ${ }^{*}$ star-na- (по [McCone 1991: 11], < * str̄nnéti < *strnạáti, с переносом долготы из неличных форм); др.-инд. strnáti 'breitet aus, streut' (< str-ne-à-ti), stárīman- n. 'Ausbreitung, Ausstreuung'. ॥ [McCone 1991: 11; Matasović 2009: 354; KEWA III: 517-518].

К структуре корня: см. под А. -по-основы, 2, кельт. *starno-.

12а. Отглагольное имя на -по-: кельт. *starno- 'pavement' др.-инд. part. stīrná- 'ausgebreitet, hingestreut', strṇấti 'breitet aus, streut', stárī-man- 'Ausbreitung, Ausstreuung'. || [Matasović 2009: 354; KEWA III].

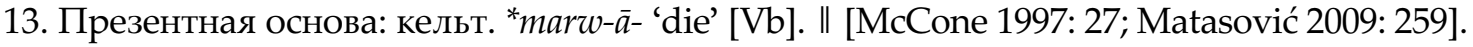

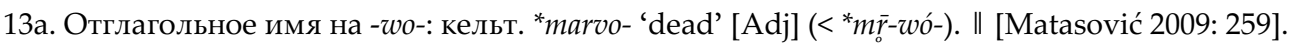

\section{3) Метатеза рефлексов краткого и долгого слоговых сонантов в а. п. $c$.}

14. Презентная основа: кельт. *fel-na- < *fil-ná- 'approach, drive' [Vb] (не < ${ }^{*} f a l-n a-$, как в

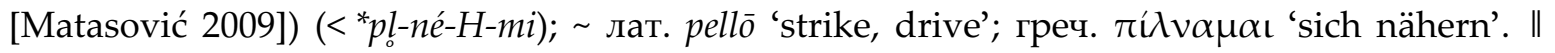
[McCone 1991: 19; Matasović 2009: 121; WH II: 276-277; Frisk 1960-1972 II: 536, 494-495].

К структуре корня: см. под А. -to-основы, 11, кельт. *falto-.

14а. Отглагольное имя на -to-: кельт. *falto- 'joint' [Noun]: др.-ирл. alt [o n] 'joint, articulation, state' (< * pl-tó< *plH-tó-). II [Matasović 2009: 121; WH II: 276-277; Frisk 1960-1972 II: 536, 494-495]; см. под А. -to-основы, 11.

15. Презентная основа: кельт. *fer-na- <*fir-na- 'bestow' [Vb] (не *far-na-, как в [Mataso-

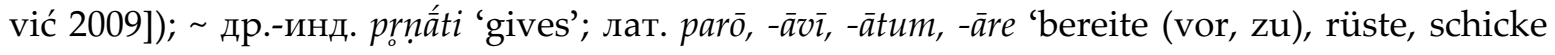
mich an; verschaffe mir, erwerbe, kaufe', 'prepare’. II [Matasović 2009: 122; WH II: 256-257].

К структуре корня: и.-е. корень “реra- 'zuteilen' (в ларингалистической интерпретации и с уточнением (расширением) значения: “perh $3^{-}$'verschaffen, zuteilen'): др.-инд. вед. prṇáti 'gibt, schenkt, spendet', pūrtá- n.,

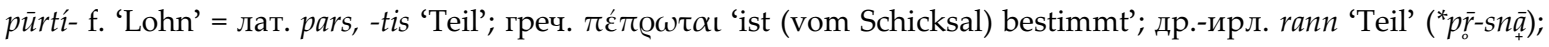
др.-ирл. ern(a)id 'gewährt', ro-rath 'ist gewährt worden' ( ${ }^{*} p \bar{r}$-to-). ॥ [IEW: 817 ( ${ }^{*}$ pera- 'zuteilen'); LIV $2: 474-475$ $\left({ }^{*}\right.$ perh $_{3^{-}}$'verschaffen')].

15а. Отглагольное имя на -to-: кельт. *fra-to-; здесь мы обнаруживаем, как и в ряде других случаев, метатезированный вариант «сокращенного» рефлекса долгого слогового сонанта, то есть рецессивный долгий слоговой сонант ведет себя как перед доминантным суффиксом, см. 16b. ॥| [Matasović 2009: 122; WH II: 256-257].

15b. Отглагольное имя на -to-: кельт. *fra-to- 'grace, virtue, good fortune' [Noun]. II [Matasović 2009: 140, 122; WH II: 256-257].

16. Презентная основа: кельт. ${ }^{*} k^{w} e l-n a-$ 'go around' $[\mathrm{Vb}]<{ }^{*} k^{w i} i l-n a-$ (не ${ }^{*} k^{w} a l-n a-$, как в [Matasović 2009: 174]); др.-инд. cárati 'bewegt sich, wandert, weidet, treibt', cáritum, caritá-, cìrná-, carítra-; лат. colo 'inhabit, take care of, cultivate'. ॥ [Matasović 2009: 174; IEW: 639-640; $\left.\mathrm{LIV}_{2}: 386-388\right]$. 


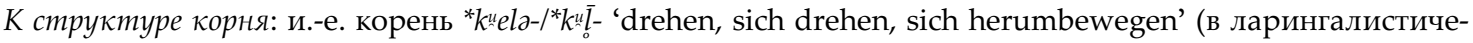
ской интерпретации: * $\left.k^{u} e l H-{ }^{*}{ }^{*}{ }^{u} l-1 H-\right)$ : др.-инд. cárati 'bewegt sich, wandert, weidet, treibt', cáritum, caritá-, cīrná-,

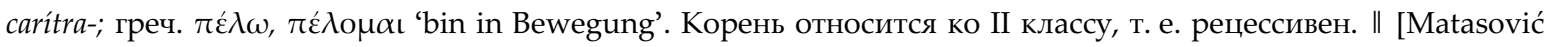
2009: 174; IEW: 639-640; $\mathrm{LIV}_{2}$ : 386-388; Николаев - Старостин 1982].

17. Презентная основа: кельт. *ster-na- < ${ }^{*}$ stir-na- 'strew, broaden' [Vb] (не *star-na-, как в [Matasović 2009: 354]); лат. sternō, strāvī, strātum, -ere 'breite aus, breite hin, streue hin'; др.-инд. strṇấti 'breitet aus, streut' RV (< $\left.{ }^{*} s t r-n e-\partial ̃-t i\right)$, stárī-man- n. 'Ausbreitung, Ausstreuung'. \| [Matasović 2009: 354; McCone 1991, 26; WH II: 590-591; KEWA III: 517-518; IEW: 10291030].

К структуре корня: см. под А. -по-основы, 2, кельт. *starno-.

17а. Отглагольное имя на -по-: кельт. *starno- 'pavement' др.-инд. part. stīrná- 'ausgebreitet, hingestreut',

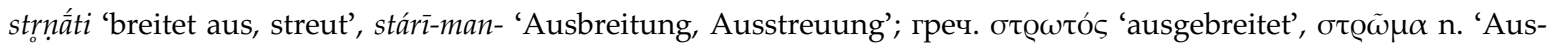
gebreitetes, Teppich, Lager'. ॥ [Matasović 2009: 354; KEWA III: 517-518; IEW: 1029-1030]; см. под А. -поосновы, 2.

Представленные выше рефлексы отглагольных имен на -to-, -tu- и -no- довольно хорошо согласуются с установленной в балтославянском системой акцентуационных валентностей, но рефлексация двух основ окситонированного типа (а. п. с) заставляет принять для кельтского материала лабильность по отношению к валентностям для двух и.-е. корней: ل`

Поскольку рефлексы $a r-, a l-$, приписываемые кратким слоговым сонантам перед -n-, встречаются исключительно в презенсах с -n-суффиксами (инфиксами), то их следует рассматривать как результат восстановления долготы корневого слогового сонанта под влиянием неличных форм. Аналогичные рефлексы в -іо-презенсах также, вероятно, не следует приписывать закону Пино, так как достаточно большой материал не поддерживает предположение о наличии этого закона в кельтском. Наблюдается также возможность двойственности рефлексации кратких слоговых сонантов: ri, li, ni под ударением, -ir, -il, -in в предударном положении; но обследованный материал пока слишком мал.

\section{Источники}

Цв. - Триодь Цветная. М., 1591.

Ев.-апр. - Ев.-апр. № 7364 - Евангелие-апракос (полный), сербская рукопись XV в. РГБ, отдел рукописей, ф. 178, № 7364 .

Чуд. - Чудовский Новый Завет, XIV в. Цитируется по изданию: Новый Завет господа нашего Иисуса Христа. Труд святителя Алексия Митрополита Московского и всея Руси. Фототипическое издание Леонтия, Митрополита Московского. М., 1892.

Хлуд. - Почерк 112-159б в рукописи: Сборник, 1560-е гг. ГИМ, Хлуд. 147Д (§ 1.28)
Сб. №151 - Сборник: среднеболгарская рукопись начала XV века. Библиотека Зографского монастыря, № 151. Четыре листа из этой рукописи находятся в РГБ, № 3070.

Тар. - Псалтирь. М., 1568 (§ 1.27).

Увар. - Кормчая, сер. XVI в, ГИМ, Увар. 296 (§ 1.30).

Сенн. - Толкование Феофилакта болгарского на евангелие от Матфея и от Марка, 1499-1500 г., ГИМ, Синод. 302. 


\section{Сокращения}

ОСА (Словарь) = Дыбо, Замятина, Николаев 1993.

Усп. Сб. = Князевская и др. 1971

ЭССЯ = Трубачёв 1972-

DK = Daukša et al. 1995

DP $=$ Wujek et al. 1926

EWA = Mayrhofer 1986-2001.
IEW = Pokorny 1959

KEWA = Mayrhofer 1956-1980

$\mathrm{LIV}_{2}=$ Rix 2001

Mühl. - Endz. $=$ Mühlenbachs 1923-1932

$\mathrm{WH}=$ Walde, Hofmann 1930-1956.

\section{Литература}

Дыбо В. А. 1961. Сокращение долгот в кельто-италийских языках и его значение для балтославянской и индоевропейской акцентологии. Вопросы славянского языкознания 5. Москва. С. 9-34. [Dybo, V. A. 1961. Sokrashchenie dolgot v kel'to-italijskikh yazykakh i ego znachenie dlya balto-slavianskoj i kel'to-italijskoj akcentologii. Voprosy slavyanskogo yazykoznaniya 5. Moskva. S. 9-34.]

Дыбо В. А. 1974. Афганское ударение и его значение для индоевропейской и балто-славянской акцентологии. I. Именная акцентуация. Балто-славянские исследования. Москва. С. 67-105. [Dybo, V. A. 1974. Afganskoe udarenie i ego znachenie dlya indoevropejskoj i balto-slavyanskoj akcentologii. I. Imennaya akcentuaciya. Balto-slavyanskie issledovaniya. Moskva. S. 67-105.]

Дыбо В. А. 1981. Славянская акцентология. Опыт реконструкции системы акцентных парадигм в праславянском. Москва. [Dybo, V. А. 1981. Slavyanskaya akcentologiya. Opyt rekonstrukcii sistemy akcentnykh paradigm $v$ praslavyanskom. Moskva.]

Дыбо В. А. 2000. Морфонологизированные парадигматические акцентные системы. Типология и генезис. Т. 1 . Москва. [Dybo, V. A. 2000. Morfologizirovannye paradigmaticheskie akcentnye sistemy. Tipologiya i genezis. T. 1. Moskva.]

Дыбо В. А. 2007. Балто-славянская акцентологическая реконструкция и индоевропейская акцентология (глагольная акцентная система западных индоевропейских языков). [Dybo, V. A. 2007. Baltoslavyanskaya akcentologicheskaya rekonstrukciya i indoevropeyskaya akcentologiya (glagol'naya akcentnaya sistema zapadnykh indoevropejskikh yazykov]. Tones and Theories: Proceedings of the International Workshop on Balto-Slavic Accentology. Zagreb, 2007, p. 47-73.

Дыбо В. А. 2009. О системе акцентных парадигм в прусском языке. Балто-славянские исследования XVIII. Москва. С. 131-182. [Dybo, V. A. 2009. O sisteme akcentnykh paradigm v prusskom yazyke. Balto-slavyanskie issledovaniya XVIII. Moskva. S. $131-182$.]

Дыбо В. А. 2015а. Балтославянская акцентная система и итоги индоевропейской акцентологической реконструкции. Славистички зборник, књ. 1. Нови Сад. С. 17-94. [Dybo, V. A. 2015. Baltoslavyanskaya akcentnaya sistema i itogi indoevropejskoj akcentologicheskoj rekonstrukcii. Slavistički zbornik, knj. 1. Novi Sad. S. 17-94].

Дыбо В. А. 2015б. Язык - этнос - археологическая культура (северо-западная группа индоевропейских языков с точки зрения акцентологии). Актуальные этноязыковые и этнокультурные проблемы современности. Книга 2. Москва. С. 138-193 [Dybo, V. А. 2015a. Yazyk - etnos - arkheologicheskaja kul'tura (severo-zapadnaya gruppa indoevropejskikh yazykov s tochki zreniya akcentologii). Aktual'nye etnoyazykovye i etnokul'turnye problemy sovremennosti. Kniga II. Moskva. S. 138-193.]

Дыбо В. А., Замятина Г. И., Николаев С. А. 1993. Основы славянской акцентологии. Словарь. Непроизводные основы мужского рода. Москва. [Dybo V. A., Zamyatina G. I., Nikolaev S. L. 1993. Osnovy slavyanskoj akcentologii. Slovar'. Neproizvodnye osnovy muzhskogo roda. Moskva.]

Зализняк А. А. 2011. Труды по акцентологии. Том 2. Аревнерусский и старовеликорусский акцентологический словарь-указатель (XIV-XVII вв.). Москва. [Zalizniak A. A. 2011. Trudy po akcentologii. Tom 2. Drevnerusskij $i$ starovelikorusskij akcentologicheskij slovar'-ukazatel' (XIV-XVII vv.). Moskva.]

Зализняк А. А. 2014. Аревнерусское ударение. Общие сведения и словарь. Москва. [Zalizniak A. A. 2014. Drevnerusskoe udarenie. Obschie svedeniya i slovar'. Moskva.]

Иллич-Свитыч В. М. 1962. К истолкованию акцентуационных соответствий в кельто-италийском и балтославянском (о «втором правиле Дыбо»). Краткие сообцения Института славяноведения. Москва. С. 63- 
72. [Illich-Svitych V. M. 1962. K istolkovaniyu akcentuacionnykh sootvetstvij v kel'to-italijskom i baltoslavyanskom (o «vtorom pravile Dybo»). Kratkie soobscheniya Instituta slavyanovedeniya. Moskva. S. 63-72.]

Дьюис Г., Педерсен Х. 1954. Краткая сравнительная грамиатика кельтских языков. Москва. [Lewis H., Pedersen H. 1954. Kratkaya sravnitel'naya grammatika kel'tskikh yazykov. Moskva.]

Николаев, С. А. 1983. К исторической морфонологии древнегреческого глагола (части 1-я и 2-я). Балтославянские исследования 1982. Москва. С. 68-103. [Nikolaev, S. L. 1983. K istoricheskoj morfonologii drevnegrecheskogo glagola (chasti 1-ya i 2-ya). Balto-slavyanskie issledovaniya 1982. Moskva. S. 68 - 103.]

Николаев С. А. 1986. К исторической морфонологии древнегреческого глагола (часть 3-я). Балто-славянские исследования 1984. Москва. С. 157-208. [Nikolaev, S. L. 1986. K istoricheskoj morfonologii drevnegrecheskogo glagola (chast' 3-ja). Balto-slavyanskie issledovaniya 1984. Moskva. S. 157-208.]

Николаев, С. А., Старостин С. А. 1982. Парадигматические классы индоевропейского глагола. БалтоСлавянские исследования 1981. Москва. С. 261-343. [Nikolaev, S. L., Starostin S. A. Paradigmaticheskie klassy indoevropejskogo glagola. Balto-slavyanskie issledovaniya 1981. Moskva. S. 261-343.]

Трубачёв О. Н. (ред.). 1972-. Этимологический словарь славянских языков. Москва. [Trubachëv О. N. $1972-$. Etimologicheskij slovar' slavyanskikh yazykov. Moskva.]

Князевская О. А., Демьянов В. Г., Аяпон М. В. 1971. Успенский сборник ХІІ-ХІІІ вв. Москва. Указываются столбцы рукописи. [Knyazevskaya O. A., Dem'yanov V. G., Lyapon M. V. 1971. Uspenskij sbornik XII-XIII vv. Moskva.]

Фасмер М. 1964-1973. Этимологический словарь русского языка. 4 тома. Москва. [Fasmer. M. 1964-1973. Etimologijeskij slovar' russkogo yazyka. 4 toma. Moskva.]

Barber, C. C. 1932. Die vorgeschichtliche Betonung der Germanischen Substantiva und Adjektiva. Heidelberg.

Bartholomae, Chr. 1904. Altiranisches Wörterbuch. Straßburg.

De Bernardo Stempel, P. 1999. Nominale Wortbildung des älteren Irischen: Stammbildung und Derivation. Tübingen.

Daukša, M., V. Jakštienė, J. Palionis, and J. Ledisma. 1995. Mikalojaus Daukšos 1595 metu katekizmas. Katechismus von Mikalojus Daukša vom Jahre 1595. Vilnius.

Falileyev, A. 2000. Etymological Glossary of Old Welsh. Tübingen.

Feist, S. 1939. Vergleichendes Wörterbuch der gotischen Sprache. Leiden.

Fraenkel, E. 1962-1965. Litauisches etymologisches Wörterbuch (2 volumes). Heidelberg.

Frisk 1960-1972, H. Griechisches Etymologisches Wörterbuch (3 volumes). Heidelberg.

Grassmann, H. 1976. Wörterbuch zum Rig-Veda. Wiesbaden.

Heidermanns, F. 1993. Etymologisches Wörterbuch der germanischen Primäradjektive. Berlin.

Holthausen, F. 1934. Altenglisches etymologisches Wörterbuch. Heidelberg.

Irslinger, B. S. 2002. Abstrakta mit Dentalsuffixen im Altirischen. Heidelberg.

Isaac, G. R. 2007. Studies in Celtic sound Changes and their Chronology. Innsbruck.

Karulis, K. 2001. Latviešu etimoloǵijas vārdnīca. Riga.

Kortlandt, F. 1981. More Evidence for Italo-Celtic. Ériu 32: 1-22.

Kroonen, G. 2013. Etymological Dictionary of Proto-Germanic. Brill.

Lexers, M. 1956. Mittelhochdeutsches Taschenwörterbuch. Leipzig.

Loth, J. 1883. Vocabulaire vieux-breton avec commentaire contenant toutes les gloses en vieux-breton, gallois, armoriques, connues, précédé d'une introduction sur la phonétique du vieux-breton et sur l'âge et provenance de gloses. Paris.

Matasović, R. 2009. Etymological Dictionary of Proto-Celtic. Leiden.

McCone, K. 1991. The Indo-European Origins of the Old Irish Nasal Presents, Subjunctives and Futures. Innsbruck.

Mayrhofer M. 1956-1980. Kurzgefaßtes etymologisches Wörterbuch des Altindischen (4 volumes). Heidelberg,

Mayrhofer M. 1986-2001. Etymologisches Wörterbuch des Altindoarischen (3 volumes). Heidelberg.

Meyer, K.H. 1935. Altkirchenslavisch-griechisches Wörterbuch des Codex Suprasliensis. Glückstadt.

Meyer-Lübke, W. 1935. Romanisches etymologisches Wörterbuch. Heidelberg.

Mühlenbachs, K. 1923-1932 Latviešu valodas vārdnīca (prepared for publication by J. Endzelin, 4 vols). Riga.

Orel, V. 2003. A Handbook of Germanic Etymology. Leiden.

Pedersen H. 1908-1913. Vergleichende Grammatik der keltischen Sprachen (2 volumes). Göttingen.

Pokorny, J. 1959. Indogermanisches etymologisches Wörterbuch. Bern.

Rasmussen, J.E. 1989. Studien zur Morphophonemik der indogermanischen Grundsprache. Innsbruck.

Raven, F.A. 1963-1967. Die schwachen Verben des Althochdeutschen (2 volumes). Gießen. 
Rix, H. 2001. Lexikon der indogermanischen Verben (2 ${ }^{\text {nd }}$ edition). Wiesbaden.

Seebold, E. 1970. Vergleichendes und etymologisches Wörterbuch der germanischen starken Verben. The Hague / Paris.

Skok, P. 1971-1973. Etimologijski rječnik hrvatskoga ili srpskoga jezika (3 volumes). Zagreb.

Smoczyński, W. 2007. Słownik etymologiczny języka litewskiego. Vilnius.

Stokes, W. 1860. Cambrica. Transactions of Philological Society 7: 204-249.

Stokes, W. 1894. Urkeltischer Sprachschatz. Göttingen.

Thurneysen, R. 1980. A Grammar of Old Irish. Revised and enlarged Edition with Supplement. Dublin.

Trautmann, R. 1923. Baltisch-Slavisches Wörterbuch. Göttingen.

Vitkauskas, V. 1976. Šiaurès rytų dūnininku šnektu žodynas. Vilnius.

de Vries, J. 1977. Altnordisches etymologisches Wörterbuch (2nd ed.). Leiden.

Walde, A. and J.B. Hofmann. 1930-1956. Lateinisches etymologische Wörterbuch (2 volumes). Heidelberg,

Wujek, J, M. Daukša, and M. Biržiška. 1926. Daukšos Postilè. Fotografuotinis leidimas. Kaunas.

Vladimir Dybo. Proto-Celtic accent system against the background of other north-western Indo-European languages.

In this paper, I revisit the results of my 1961 study on the shortenings of unaccented IndoEuropean long vowels in Italo-Celtic languages. A significant amount of new material confirming the original hypothesis has been uncovered; however, some of the results are modified as I demonstrate another type of shortenings of the original long sonorants in Celtic languages. I also show that interpretation of the discovered rules in the laryngealistic paradigm is compatible with a more traditional interpretation.

Keywords: prosodic reconstruction, Celtic languages, vowel shortening, accent paradigms, metatony 
